\title{
THE CASE FOR A CHARITABLE CONTRIBUTIONS DEDUCTION
}

\author{
Mark P. Gergen*
}

\begin{abstract}
LTHOUGH the deduction for charitable contributions has long Abeen a part of the incoine tax, ${ }^{1}$ its desirability is still contested. Even advocates of a deduction disagree over its rationale, and soine commentators argue that there should be no deduction. ${ }^{2}$ There is also disagreement on what should count as "a charity" for purposes of a deduction. Economists question the deduction for gifts to certain
\end{abstract}

* Assistant Professor, University of Texas School of Law. I would like to thank Patricia Cain, Joseph Dodge, John Dzienkowski, Calvin Johnson, Richard Markovits, Charles Silver, and the participants in the University of Texas Writers Workshop for their helpful conıments on earlier drafts. I owe special thanks to David Gunn for finding obscure niaterials.

1 The deduction is codified at I.R.C. $\$ 170$ (1982 \& Supp. IV 1986). The heart of the statutory definition of entities to which deductible contributions may be made is I.R.C. $\S 170(c)(2)$ :

A corporation, trust, or community chest, fund, or foundation ... (B) organized and operated exclusively for religious, charitable, scientific, literary, or educational purposes, or to foster national or international amateur sports conpetition (but only if no part of its activities involve the provision of athletic facilities or equipment), or for the prevention of cruelty to children or animals .... .

Other entities defined as charities include states and their political subdivisions, I.R.C. $\S 170(c)(1)$, veterans organizations, I.R.C. $\S 170(c)(3)$, fraternal organizations (but only if the contribution is used for the purposes otherwise defined as charitable), I.R.C. $\S 170(c)(4)$, and cemetery associations, I.R.C. $\$ 170(c)(5)$.

Congress first adopted a contributions deduction in 1917. War Revenue Act, ch. 63, $\S 1201(2), 40$ Stat. 300,330 (1917). Entities to which deductible contributions could be n1ade were defined as "corporations or associations organized and operated exclusively for religious, charitable, scientific or educational purposes, or to societies for the prevention of cruelty to children or animals. ..." Id. Charities were exenupted from this and earlier versions of the income tax. See Persons, Osborn, and Feldman, Criteria for Exemption Under Section 501(c)(3), in 4 Conun'n on Private Philanthropy and Pub. Needs, Research Papers 1909, 1924 25 (1977) [hereinafter Research Papers].

2 See, e.g., U.S. Dept. of the Treasury, Blueprints for Basic Tax Reform 95-96 (1977) [hereinafter Blueprints]; Kelman, Personal Deductions Revisited: Why They Fit Poorly in an "Ideal" Income Tax and Why They Fit Worse in a Far From Ideal World, 31 Stan L. Rev. 831 (1979). In its sweeping reform proposals of 1984 the Treasury Department advocated restricting the deduction to contributions in excess of two percent of adjusted gross inconie and denying it to nonitemizers. Office of the Sec'y, U.S. Dept. of the Treasury, 1 Tax Reform for Fairness, Sinıplicity, and Economic Growth 81-83 (1984) [hereinafter Tax Reform for Fairness]. 
kinds of charities, such as churches. ${ }^{3}$ And, in Great Britain, which has a provision in its tax law akin to a contributions deduction, there have been efforts to restrict it to poor rehef, distress relief, education, research, and retigion. ${ }^{4}$

The objective of this Article is to answer (or at least to suggest how we might go about answering) two fundamental questions: Why should there be a deduction and which transfers to what enterprises should be deductible? Parts I through III examine three theories supporting some form of a deduction or tax credit for contributions. First in importance in the literature is the theory that a deduction efficiently subsidizes collective goods provided by charities. ${ }^{5}$ The other prominent theory is Professor William Andrews's argument that a deduction is intrinsic to the purposes of an income tax because transfers to charity are not personal consumption. ${ }^{6}$ The third theory, which has few proponents (one of whom is Professor Boris Bittker), ${ }^{7}$ is that a deduction equitably accounts for the loss in welfare suffered by people who transfer their resources to charity. This Article concludes that the subsidy and equity theories-the first and third-are valid subject to significant nornative and einpirical constraints. It rejects Andrews's theory as, at best, a reformulation of the efficient subsidy theory.

Part IV apphes the subsidy and equity theories to three types of charities-churclies, public television, and social welfare agencies. It concludes that a deduction for gifts to social welfare agencies is justified under either the subsidy or equity theory, and that a deduction for gifts to public television is justified under neither theory. The two theories point in different directions im the case of churches. A deduction for gifts to churches is not justified as a subsidy because churches

3 See C. Clotfelter, Federal Tax Policy and Charitable Giving 23-24 (1985); Vickrey, One Economist's View of Philanthropy, in Philanthropy and Public Policy 45 (F. Dickinson ed. 1962); M. Taussig, The Charitable Contributions Deduction in the Federal Income Tax 25 (Ph.D. dissertation, M.I.T. 1965).

4 Royal Comm'n on the Taxation of Profits and Income, Final Report 57 (1955).

5 C. Clotfelter, supra note 3, at 280-85 (summarizing much of the literature).

6 Andrews, Personal Deductions in an Ideal Income Tax, 86 Harv. L. Rev. 309 (1972).

7 See Bittker, Charitable Contributions: Tax Deductions or Matching Grants?, 28 Tax L. Rev. 37, 58-59 (1972); see also Commission on Private Philanthropy and Public Needs, Giving in America: Toward a Stronger Voluntary Sector 128 (1975) (arguing that gifts to charity should be deductible because the person who gives is less well of than the person who spends money in other ways). 
do not seem to suffer greatly from freeriding and so should not be underfunded. It may be, however, that rehgious giving is self-abnegating and made from a sense of religious obligation. If this is true, a deduction for gifts to churches inay be justified on equitable grounds.

The theories mentioned above, of course, are not the only ones supporting a deduction. ${ }^{8}$ Solnetimes it is said that a deduction promotes the act of giving which is itself worthwhile. A version of this is the argument that a deduction serves as a reward for selfless behavior. ${ }^{9}$ If what we prize in giving is its selflessness, though, why should we sully that with a pecuniary reward? Moreover, as we shall see, much giving is selfish because it pays for goods donors enjoy. There is also a claim that charity is a high form of self-expression deserving encouragement. ${ }^{10}$ But, without taking into account the merit of what charities do, it is difficult to see why we should feel differently about charitable giving than about other ways people spend their money. My purchase of season tickets to see the Texas Longhorns play football is a form of self-expression. Why is it not equally deserving of a tax preference? To say that it is not you must look past the act to the worthiness of its ends. To tell what is worthy you need soine other theory.

Often a deduction is justified on the ground that a charitable cause is good or just and therefore ought to be supported in whatever way it can be. Usually this type of argument is made unthinkingly by advocates of a particular cause (educators, for example, need only see that it is a source of revenues to then to know that a deduction is good), though one could construct elaborate ethical arguments to justify a deduction in particular cases (is not a deduction for gifts to social welfare agencies, assuming it assures thein of more resources, consistent with Rawls's inaximin rule? $\left.{ }^{11}\right)$. These arguments are value based

8 Some arguments are addressed in the course of discussing one of the theories given primary attention in this Article. Thus, the claim that a deduction encourages diversity and experimentation is examined in explaining why collective goods might better be subsidized through a deduction than through direct government grants, see infra notes 48-53 and accompanying text, and the claim that a deduction is necessary because of some other provision of the tax laws is dealt with in discussing Andrews's theory. See infra notes 83-90 and accompanying text.

9 Bittker, supra note 7, at 60-61.

10 O'Connor, Philanthropy and Selfishness, Social Phil. \& Pol., Spring 1987, at 113.

11 See generally J. Rawls, A Theory of Justice 60-65, 150-61 (1971) (rule that, to be just, any social arrangement resulting in inequality must benefit the least well-off). A justification of a deduction along these lines is sketched in Atkinson, The Income Tax Treatment of Charitable Contributions, in Public and Urban Economics 13 (R. Grieson ed. 1976). 
in a way that the theories examined in this Article are not. Values undergird the theories examined herein at length (the subsidy theory values efficiency and the equity theory rests on a view of what an incoine tax ought to do), but these theories do not depend upon claims about the moral worth of what charities do. The case for a deduction on efficiency or equity grounds turns, at last, on einpirical questions (Are charities underfunded because of freeriding? Do gifts reduce the welfare of donors?) that inay be answered without regard to whether charities' activities are themselves good or just.

Arguments resting on a claim that in a good or just society we would do more of whatever a charity does are very different. Such arguments for a deduction will often founder on the shoals of skepticism. Some causes are controversial (churches and poor rehef), some trivial (public television), but few are easily said to be morally privileged (orphanages maybe). And it inay be that private charity is not a good way to do things we think must be done in a just society. Charitable donors are free to give to whatever causes they wish, and inevitably some "wrongheaded" people will support the wrong things (satamists churches or racist schools) and refuse to support the right things. Claims for the moral priority of charitable causes cannot justify a deduction in anything hike its present form.

\section{SUBSIDY}

Congress first adopted a contributions deduction in $1917^{12}$ in order to ensure that the income tax would not suppress giving to charity. ${ }^{13}$ To encourage giving is to this day the major rationale for a deduction. However, in seventy years our understanding of why some charities deserve subsidy and, as importantly, why a deduction (or a tax credit for donation ${ }^{14}$ ) is sometimes the best way to provide that subsidy, has advanced significantly. The first section of Part I examines the abstract and highly formal models of William Hochman and James

12 See supra note 1.

13 See, e.g., 55 Cong. Rec. 6,728 (1917) (statement of Senator Hollis).

14 The two generally are interchangeable for the purposes of this Articie. In situations where there is a relevant difference between a deduction and a credit it will be noted. Where there is no relevant difference, the expression "tax-free treatment" or the like is sometimes used to include both treatments. 
Rodgers ${ }^{15}$ and of Burton Weisbrod. ${ }^{16}$ Hochman and Rodgers show that, under ideal conditions, allowing a deduction or credit for contributions may be Pareto superior to not having one. Weisbrod identifies the circumstances in which a collective good is better provided by private charity than by government.

The second section of this Part proposes several refinements to the subsidy theory. It proposes that the theory must be modified to account for the pleasure people take in voluntary giving, and it suggests a category of public goods which do not deserve subsidy. It also concludes that the appropriate standard of efficiency in determining the desirability of a contributions deduction is Kaldor-Hicks and not Pareto. The Kaldor-Hicks standard better accounts for the fact that there will always be some who disapprove of a deduction. Moreover, the Kaldor-Hicks Standard better accounts for the redistributive goals of some charities.

\section{A. The Basic Theory}

The starting point of the subsidy theory is the observation that charities provide public goods which we wish to have provided without charge to their beneficiaries. Two qualities define a public (or collective) good: one person's consumption of the good does not reduce its availability to others (i.e., the good is nonrival or in joint supply); and no one can be excluded from the good (i.e., the good is nonexclusive). ${ }^{17}$ To be public, a good need not be purely nonrival and nonexclusive. It is sufficient that the cost of excluding an individual is greater than the marginal cost of supplying the good to her as an additional user. It is then cheaper to supply the good freely than to charge each user for it.

A charity performing basic scientific research may provide close to a pure public good. One person's benefiting from a scientific advance usually does not diminish the benefits others receive, and it is difficult to charge all who gain from it as its benefits ripple through society. Disaster and poverty relief also may be considered close to pure pub-

15 Hochman \& Rodgers, The Optimal Tax Treatment of Charitable Contributions, 30 Nat. Tax J. 1 (1977), reprinted in The Economics of Nonprofit Institutions 224 (S. Rose-Ackerman ed. 1986).

16 Weisbrod, Toward a Theory of a Voluntary Nonprofit Sector in a Three-Sector Economy, in The Economics of Nonprofit Institutions, supra note 15, at 21.

17 R. Boadway \& D. Wildasin, Public Sector Economics 57 (2d ed. 1984). 
lic goods if one empliasizes the benefits that accrue to society generally-e.g., msurance, relieving knowledge of other people's suffering, or easing potential social tension-and not the specific assistance given to individuals or the specific pleasure donors obtain from giving. Churclies, museums, and scliools are not public goods in this strict sense of the term because they benefit parishioners, patrons, and students who could be made to pay for what they receive. They may, however, be thought of as impure public goods because of their secondary benefits. ${ }^{18}$ The moral or intellectual education of parishioners and students indirectly benefits everyone in the conimunity, and the presence of cliurches, museums, and scliools makes a community a more stimulating and attractive place to live for everyone. Some charities, sucl as public television, may not provide significant collective secondary benefits. Nevertheless, we might classify what they provide as public goods because we believe that it is too expensive to charge users (though it is feasible), or because there are otlier reasons to provide public television freely (perliaps a distributional or educational policy.)

Cliarities that provide goods for which we cannot or do not wisl to charge beneficiaries deserve government support because, without the subsidy, society will tend to underfund thein. The principal reason for this tendency is freeriding. Some people will refuse to pay for a good and rely on others to sustam it. Their refusal discourages more conscientious people from giving, because even conscientious people may not want to be taken advantage of by freeriders or they may despair of the possibility of successful collective action. The undiscouraged still may undergive because they undervalue collective goods, something that is easy to do because there is no market to set a price for the good. Finally, some goods will be underfunded because people who support and priniarily benefit from thein fail to account for their secondary collective benefits. For example, a student may place less value on her education than does society and thus underinvest in education.

This mucl of the analysis is fairly straightforward, tlough of course one may question its premises. One may argue, for example, that churclies are not truly public goods, or that it is perverse to say

18 See Lancaster, The Pure Theory of Impure Public Goods, in Public and Urban Economics, supra note 11 , at 127 . 
that the benefit of poor rehef relevant to justifying the deduction is the collective benefit to society at large and not the private benefit to the poor themselves. These issues are better dealt with after the full subsidy theory has been elaborated. For now, the interesting question is why, assuming subsidization is the goal, a deduction (or a credit) is preferable to direct government support as a way of subsidizing charities.

Recent works by Harold Hochman and James Rodgers and by Burton Weisbrod explain the advantages of tax-free private charity as a inechanism for funding collective goods. Weisbrod's insight is that private charity probably responds better to differences in demand for collective goods than government does. ${ }^{19}$ The virtue of private giving is that it enables smaller groups to act collectively without having to secure direct government expenditures for the good through the pohitical process. If there is a high preference minority and a relatively mdifferent inajority, a tax subsidy for private funding of the good inay be the only way to fund the good at the level the minority desires. Left to its own devices without a tax subsidy, the minority may not be able to overcoine its freerider problems to provide the appropriate amount of the good. ${ }^{20}$

19 Weisbrod, supra note 16 , at 31 . He is concerned with explaining the role of charities in a market economy and notes only in passing that charities should be supported through a deduction. Id. at 36.

20 This analysis suggests that if demand for a good is homogeneous-that is, if preferences for it do not vary among individuals-it is probably better provided directly by government. If demand is homogeneous government should, in theory, not fail to fund a collective good at an optimal level. Consider a society of five persons $(A, B, C, D$, and $E)$ who are contemplating a four-unit collective good, an increasingly ornate statue. Each increment of the statue costs $\$ 100$ and each person derives $\$ 20$ of benefit from the last unit. There should be no impediment to their voting to tax themselves $\$ 80$ each to build a $\$ 400$ statue: that is the optimal solution for everyone.

Of course, they may fail to reach this solution for any number of reasons. But subsidizing voluntary funding of the statue with a deduction may only make failure more likely. If $D$ and $E$ give and the rest freeride, for example, often the freeriders will block direct government funding of the statue because they prefer paying a small percentage of the cost of a small statue to paying one-fifth the cost of a four unit statue. For a formal demonstration of this point, see Weiss, Donations: Can They Reduce a Donor's Welfare?, in The Economics of Nonprofit Institutions, supra note 15, at 45 . For instance, if $D$ and $E$ pay $\$ 200$ to fund a two-unit statue and are in a 33 percent bracket, the cost of a deduction to $A, B$, and $C$ should be approximately $\$ 13.33$ each (one-fifth of the $\$ 66.67$ loss of revenues, assuming that loss is spread evenly). The three freeriders might vote to block a four-unit statue paid for by everyone if they prefer paying $\$ 13$ for a two-unit statute to paying $\$ 80$ for a four-unit statue. 
Hochman and Rodgers further explain why it may be desirable to provide public support for contributions to charity through a tax credit. The heart of their argument is a simple intuition: A credit will push funding of a collective good closer to an optimal level by shifting part of the cost of the good from donors to freeriders. ${ }^{21}$ More precisely, they slow that a credit for gifts to cliarity may approximate what economists call a Limdahl solution (or benefits pricimg). ${ }^{22}$ In a Lindahl solution, a collective good is funded at the level where the sum of the mcremental benefits individuals derive from the last unit of the good equals the marginal cost of that unit, and eacli individual contributes an amount equal to lier marginal benefit from the last unit of the good times the number of units provided. ${ }^{23}$ For example, in a society of three people $(A, B$, and $C)$, in whicl $A$ and $B$ value the second unit of a park at $\$ 0.50, C$ values the second unit at $\$ 2.00$, and eacli unit of the park costs $\$ 3.00$, the Lindahl solution for funding the park would be to expend $\$ 6.00$ on a two-unit park and $\operatorname{tax} A$ and $B$ $\$ 1.00$ ( $\$ 0.50 \times 2$ units) and $C \$ 4.00$ (\$2.00 X 2 units). ${ }^{24}$ Hochman and Rodgers's point is that providing $C$ a credit for his gift to the park may encourage lim to give $\$ 6.00-\$ 2.00$ more than lie values the

21 Hochman \& Rodgers, supra note 15, at 228-32. The fact that the scope of many charities is regional or local does not greatly affect the analysis. One might argue that it is unfair and inefficient to tax New Yorkers to support a Texas public hospital by allowing Texans to deduct gifts to their local hospital on their federal income tax. This is similar to an argument against deducting state and local taxes. See Tax Reform for Fairness, supra note 2, at 78. But there is no problem so long as every community has a public hospital funded at comparable levels by gifts or by local government. Then a deduction for contributions does not shift resources from one community to another; rather, it shifts parts of the cost of the hospitals to freeriders in each community. Each community is able to fund its hospital at closer to an optimal level while reaping the benefits of maintaining it locally. There are advantages in local charities that justify some slight interregional inequities. Local charities are more likely to be sensitive to local needs. They may be less expensive to administer, if only because they avoid surplus levels of administration. And they have decided advantages in fundraising. Altruistic impulse, the desire for insurance against the possibility that one may become destitute, and other motives for giving to the needy are likely to be most strongly felt when the poor people being helped are neighbors.

22 Hochman \& Rodgers, supra note 15, at 233-35.

23 R. Boadway \& D. Wildasin, supra note 17, at 91-93.

24 Variations in unit cost complicate the analysis. If unit cost rises, a Lindahl solution taxes people too much because it assumes earlier units cost as much as the last. This surplus must somehow be apportioned. If unit cost falls, a Lindahl solution collects too little money and some formula must be devised for apportioning that additional cost. But these complications do not alter Hochman and Rodgers's basic point that allowing a high preference minority to deduct may be the only feasible way to make the majority share the cost of funding a good from which they benefit. 
park $^{25}$ - while shifting $\$ 2.00$ of his cost to $A$ and $B$.

If tax-free private giving approximates a Lindahl solution, there is a powerful argument for a deduction or credit, because that deduction means that the policy makes soine people better off and no person worse off. An economist would say that a policy of tax relief for charitable contributions results in a Pareto inproveinent. ${ }^{26}$ For example, if $A$ and $B$ are willing to spend $\$ 0.50$ each on the second unit of the park, and a deduction encourages $C$ to spend $\$ 2.00$ on the second unit while imposing a $\$ 0.50$ cost each on $A$ and $B$, the improvement in $C$ 's welfare connes without harm to $A$ or $B$. This much is axiomatic. Under a Lindahl solution, people pay to support collective goods only up to the dollar where the marginal benefit they receive froin cominitting more resources to a good exceeds the inarginal cost to thein (or the foregone benefit of using resources in other ways). In short, people would pay for collective goods until they are happier spending their inoney in other ways. ${ }^{27}$

25 It is here assumed that $C$ values the first unit at $\$ 2.00$ as well.

26 A. Atkinson \& J. Stiglitz, Lectures on Public Economics 509 (1980).

27 Hochman and Rodgers claim that a Lindahl solution is fair, as well as efficient, because it is distributionally neutral. Hochman \& Rodgers, supra note 15, at 238; cf. R. Boadway \& D. Wildasin, supra note 17, at 92 (" $[U]$ nder a scheme of benefit pricing, each individual's total charge is equal to the marginal benefit of the public good times the quantity consumed, and again it could be argued that this is a fair way of sharing the costs of the good."). But a Lindahl solution often will not be distributionally neutral. In the Lindahl model, contributions are fixed by the marginal benefit people derive from the last unit, so each person's total benefits will vary if people derive different levels of satisfaction from earlier, or inframarginal, units of a good. Strnad, The Charitable Contribution Deduction: A Politico-Economic Analysis, in The Economics of Nonprofit Institutions, supra note 15, at 271-72. In the example of the park, $A$ will be better off than $B$ if he values units one through three of the park at $\$ 1.00$ and unit four at $\$ 0.50$ while $B$ values all four units at $\$ 0.50$. Then $A$ pays $\$ 2.00$ for a park which gives him $\$ 3.50$ worth of pleasure while $B$ pays $\$ 2.00$ for a park which gives him $\$ 2.00$ worth of pleasure.

A Lindahl solution may be defended as fair, even though it is not distributionally neutral, if one accepts that it is fair to compel people to support collective goods from which they benefit even though each person's net benefit varies. For a defense of these propositions see Arneson, The Principle of Fairness and Free-Rider Problems, 92 Ethics 616 (1982). Although most people probably agree that fairness requires people to pay something for the goods they get (other than as gifts), some moral philosophers question that proposition. See, e.g., R. Nozick, Anarchy, State, and Utopia 93-95 (1974) (arguing that it is unfair to demand compensation from someone for the benefits he derives from collective endeavors). Nozick's concern seems to be that it is unfair to force people to pay for goods which benefit them if they had no choice in accepting the benefit. Arneson responds that when individuals enjoy a collective good, under certain circumstances they have a moral obligation to help pay for it even if they never agreed to pay or consented to the good being provided. Arneson, supra, at 622-23. He also argues that the objection to coercing people to pay for collective goods is equally an objection 
There is an apparent contradiction between Weisbrod's model of charity and Hochman and Rodgers's model supporting a tax credit. For Weisbrod, heterogeneity of demand for a collective good leads to private provision of the good through charity. He would expect museums to be supported by charity instead of by taxes, for example, because people with a high preference for museuins would be willing to bear their cost. ${ }^{28}$ For Hochman and Rodgers, on the other hand, universality of deinand for a collective good justifies publicly underwriting it through a credit or a deduction. Tax relief for gifts to museums is proper under the Hochman and Rodgers model if everyone agrees that the benefits to them of increased funding for museums outweighs the cost to thein of a deduction. If demand for a museum is sufficiently widespread to justify tax relief for contributions, one may ask, might not we expect people to support a direct subsidy for the museuin?

The answer to this riddle hes in the allocative imperfection of taxes. People who desire more of a collective good, but who do not place great value on the increase, may refuse to support a subsidy because they fear that they will bear a disproportionate share of the tax cost. Recall our three-person society considering a two-unit park costing $\$ 3.00$ per unit. $A$ and $B$ place a $\$ 1.00$ value on a one-unit park and $\$ 0.50$ of value on the second umit. $C$ values each unit at $\$ 2.00$. If $A$ and $B$ assume that the taxes to pay for the park will be shared equally, they will refuse to vote for a two-umit park because the marginal cost to each of them $(\$ 1.00)$ outweighs the benefit $(\$ 0.50)$. The problein exists because taxes are not calibrated to account for variations in preference for goods supported by government. Tax-free treatment of contributions is so cahbrated, albeit roughly, because it imposes most but not all of the cost of increased support for a good on donors.

Of course, a deduction is also an miperfect mechanism to allocate costs of a good. A deduction diminishes the cost of contributions by an arbitrary amount depending on a donor's tax rate. Moreover, the costs of a deduction in lost revenues will be allocated capriciously.

to private property, because the institution of private property depends upon people's involuntary acquiescence to the property claims of individuals. Id. at $624-25,629$. On the second issue of whether it is fair that net benefits vary, Arneson assumes that people cannot complain if a strategy to fund a good does not make them worse off than they would be without the good.

28 Weisbrod, supra note 16 , at $37-38$. 
Who bears these costs depends upon whether taxes are raised to make up the deficit (and how they are raised), programs are cut (and what programs are cut), money is borrowed (and when it is repaid), or money is printed. No action (other than a head or flat household tax) will affect everyone equally. It is unimaginable and undesirable that in responding to a loss in revenues Congress will concern itself with the minutiae of who benefits how much from the deduction creating that loss. ${ }^{29}$

The argument for a deduction (or credit) is that, even with its flaws, it better matches expense with preference in cases of collective goods for which demand is universal but heterogeneous. If a charity cannot charge its beneficiaries and it cannot secure financial support from the government, a deduction may be the only inechanisin available to spread its cost across freeriders. It enables people with a high preference for a good to shift soine of its cost to low-preference freeriders.

Ultinately, a deduction is a fairly modest way to fund collective goods. Its cost in revenues is quite small. In 1989, revenue loss from the deduction will be approximately $\$ 12.9$ billion. ${ }^{30}$ This amounts to $\$ 133$ per household spread across ninety million housenolds. The charitable sector of the economy is simply not that large; giving to all charities may be less than two percent of personal income, ${ }^{31}$ and that figure includes gifts to all charities. If gifts to religious charities (over sixty percent of total gifts ${ }^{32}$ ) are omitted, the remaining donations

29 Even if the cost of a deduction were allocated evenly it would be insensitive to different preferences for collective goods. Consider a five person society comprising $A, B, C, D$, and $E$, with a one unit collective good, a public statue. $A$ values the statue at $\$ 1.00, B$ at $\$ 2.00$, and so on, with $E$ valuing it at $\$ 5.00$. $A$ and $B$ freeride. Through a deduction they hope, ideally, to encourage $C, D$, and $E$ to give $\$ 15$ to build the statue by shifting $\$ 3.00$ of their cost to $A$ and $B$. But, if this cost is allocated evenly between $A$ and $B$ (\$1.50 apiece), $A$ pays too much and $B$ pays too little. This problem is made worse if high-preference people (e.g., $D$ ) freeride. To tax $D$, who should pay $\$ 4.00$, adequately, we must grossly overtax $A$, who should pay only $\$ 1.00$.

30 Staff of the Joint Comm. on Taxation, 100th Cong., 2nd Sess., Estimates of Federal Tax Expenditures for Fiscal Years 1989-1993 14-15 (Comm. Print 1988). Of this amount, \$1.2 billion is attributed to gifts to health charities, $\$ 1.2$ billion is attributed to gifts to education, and $\$ 9.5$ billion is attributed to gifts to all other charities. The revenue lost because of a corporate deduction for contributions is estimated to be $\$ 1.0$ billion in 1989 . In 1985 the estimated revenue loss from an individual deduction was $\$ 15$ billion. M. Graetz, Federal Income Taxation 31 (1985).

31 See C. Clotfelter, supra note 3, at 18 (estimates for 1963-81). A more recent study reports that 2.4 percent of household income is given to charity. 30 American Ass'n of FundRaising Counsel Trust for Philanthropy, Giving USA 11 (1986) [hereinafter Giving USA].

32 C. Clotfelter, supra note 3 , at 22 (data for 1962, 1973, and 1978). 
probably represent substantially less than two percent. The improvement in social welfare from a deduction is probably small, but better than could be achieved through other policies.

Hochman and Rodgers answer a persistent argument for a deduction: the claim that a deduction gets more money to charity at lower cost to the government than would a program of direct grants. Several studies have found that the price elasticity of giving has an absolute value greater than 1.00; some studies have even estimated it to be greater than $2.00 .^{33}$ Thus, for every dollar people save in taxes and the government loses in revenue because of a deduction, more than an additional dollar, maybe more than two dollars, is given to charity. ${ }^{34}$ A favorable price elasticity, however, does not ensure that the benefits of a deduction outweigh its costs. The issue is not how much extra money is spent on charity as a result of a deduction; it is, rather, how much people benefit from that extra expenditure compared to the alternative use of the lost revenues. Two dollars spent on mime theatre, for example, may not be worth a dollar in lost revenue. Moreover, as Hochman observes, the fact that government does not fund a good directly suggests that the cost of a dollar loss of revenue exceeds the benefit of a dollar increase in contributions. (If the two were equal, society would be indifferent between direct government funding and tax-free private funding.) Thus, "in a Lindahl cost-sharing

33 See id. at 49-63 (a collection and discussion of the major studies).

34 Martin Feldstein argues that tax subsidies generally are more efficient than direct grants to charities for reasons apart from this elasticity effect. He assumes that government grants reduce private giving to the extent they satisfy people's demand for a good (the "marginal propensity to give"). Feldstein observes:

Each dollar of direct government spending ... would therefore increase the charity's budget by only this marginal propensity to give $(m)$. A tax subsidy is therefore more efficient than government spending if each dollar of revenue loss adds more than $m$ dollars to the donee's receipts. This result is assured because the introduction of a tax incentive that reduces revenues by one dollar not only increases the income of the donor by one dollar, causing his contributions to rise by $m$, but also reduces the price of giving, which will further increase giving.

Feldstem, A Contribution to the Theory of Tax Expenditures: The Case of Charitable Giving, in The Economics of Taxation 106 (H. Aaron \& M. Boskin eds. 1980). The argument is unconvincing. First, it suggests, incorrectly, that government grants reduce private giving dollar for dollar. See infra note 129 (citing evidence to the contrary). Second, it ignores the fact that most of the money given to charity is from a disproportionately small number of taxpayers. Ehminating grants may reduce the tax burden, but that benefit is shared by many who could not or would not contribute significantly regardless of the tax consequences. Feldstein is therefore wrong in assuming that the reduction of revenues from tax relief will correspond to an increase in donor income. 
scheme the community would only be satisfied if a $\$ 1.00$ marginal increment in the subsidy were to bring about much more than a $\$ 1.00$ increase in contributions." ${ }^{35}$

Weisbrod and Hochman and Rodgers also suggest answers to a persistent criticism of a deduction. Many question the propriety of vesting power to choose what charities get funded in the wealthy donor class instead of elected officials or democratic majorities. ${ }^{36}$ The use of a deduction to provide tax relief is particularly troublesome because it makes it cheaper for high-bracket taxpayers to give. A person in a thirty-three percent bracket pays, after tax, sixty-seven cents for each dollar she gives to charity. A person in a fifteen percent bracket pays eighty-five cents. A poor man who pays no taxes pays one dollar to give one dollar to charity. This is called the "upsidedown effect." 37 The after-tax cost of giving could be made the same for all taxpayers by replacing a deduction with a credit system under which some portion of amounts given to charity is credited agamst taxes owed. ${ }^{38}$ Even a credit, however, would not completely eliminate

35 Hochman, Comments, in The Economics of Nonprofit Institutions, supra note 15, at 298.

36 See, e.g., Kelman, supra note 2 , at $856-58$.

37 The changes in the tax laws in 1986 lessened, but did not completely eliminate, the upside-down effect. The compression of rates reduces the price difference in giving. Under the new rates, the difference between the highest and lowest marginal rates-and so the percentage of gifts saved-will be 18 percent (33 percent minus 15 percent) instead of 39 percent (50 percent minus 11 percent). With the highest standard rate being reached at fairly low levels of income (the basic rate is 28 percent at $\$ 29,750$ on joint returns, I.R.C. $\$ 1$ (a) (Supp. IV 1986), but a surtax of 5 percent pushes the rate to 33 percent in some cases, id. $\S 1(\mathrm{~g})$ ), even that difference quickly will disappear. One change adopted in 1986 worsens the upside-down effect. Nonitemizers no longer may claim a deduction for charitable contributions. See id. $\S 63(\mathrm{e})(1)$, $\$ 170$ (i). This means, in effect, that only homeowners will profit from the deduction for contributions, because only they are likely to have sufficient deductions for other expenditures, primarily home mortgage interest payments and property taxes, to warrant filing itemized returns. Estimated tax savings (or lost revenue) from a deduction in 1989 are $\$ 1$ million for returns with taxable income less than $\$ 10,000, \$ 72$ million for returns with income up to $\$ 20,000$, and $\$ 332$ million for returns with income up to $\$ 30,000$. For returns reporting income over $\$ 30,000$, however, the estimated savings is almost $\$ 11$ billion. Staff of the Joint Comm. on Taxation, supra note 30 , at 20.

38 C. Clotfelter, supra note 3 , at 44 . The benefit could be extended to people with too little income to be taxed by making the credit refundable if it is in excess of taxes owed. Hochman and Rodgers conclude that the optimal structure of the subsidy is probably a tax credit instead of a deduction. They think that a credit is a better means of reaching a pricing solution because benefits from collective goods (and hence the price people are willing to pay for them) are likely to increase proportionately with income. Hochman \& Rodgers, supra note 15 , at 232-36. Jeff Strnad argues, to the contrary, that accounting for the greater cost of the subsidy to high bracket taxpayers may justify use of a deduction. Strnad, supra note 27 , at 271-72. 
difficulties with funding public goods through tax-free private gifts. The choice of what goods to fund still is placed in the hands of those with wealth rather than those who vote, because only the well-to-do have sufficient disposable wealth to give much to charity. Any system in which people save taxes by giving to charity removes power from the majority and revests it in wealthy donors.

Weisbrod shows that it is naive to expect voting always to produce the optimal result. Hochınan and Rodgers answer the equitable concern. The upside-down effect is not troubling, they explain, so long as the cost of a deduction to the less wealthy (in increased taxes or foregone government services) is at least offset by the benefit to them of the additional expenditure on charity. ${ }^{39}$ For example, the poor perhaps should not complain that a deduction makes giving by the wealthy less costly if that savings prompts the wealthy to fund charities like the Red Cross or the Salvation Army which primarily benefit the poor. If the price elasticity of giving is greater than 1.00 , it inay be that the deduction amphifies the redistributive effect of the tax by encouraging the wealthy to devote more dollars to charities that benefit the poor than wealthy donors save in taxes. ${ }^{40}$

Hochman and Rodgers dismiss the concern that rich donors will bear more of the cost of a credit on the ground that its cost is likely to be so widely shared that the amount imposed on any particular individual will be infinitesimal. Hochman \& Rodgers, supra note 15, at 236.

39 The theory is not completely satisfactory on this count because, like all Pareto analyses, its determination of the optimal level of expenditure on a good takes the initial distribution of wealth as a given. See generally R. Boadway \& D. Wildasin, supra note 17, at 92 (noting that a Lindahl solution may not be distributionally just). In the example above, for instance, $A$ and $B$ 's willingness to pay $\$ 0.50$ for the fourth umit of the park and C's willingness to pay $\$ 2.50$ is, in part, a function of their wealth. If we redistribute wealth among the three (e.g., take wealth from $C$ and give it to $A$ and $B$ ), the good will be priced differently by them and the optimum will change. It is especially problematic that an analysis of a provision of $\operatorname{tax}$ law is contingent on the existing distribution of wealth because one function of the income tax is to redistribute wealth. This problem, however, is not insurmountable. We just must remember that the question of the distribution of wealth is antecedent to determiming the optimal level of expenditure on a good. At least in theory, we can determme what amount of resources people should control given our redistributive goals and then determine how they would prefer those resources be spent.

40 See Brannon, Tax Expenditures and Income Distribution: A Theoretical Analysis of the Upside-Down Subsidy Argument, in The Economics Of Taxation, supra note 34, at 87, 92-95. Similarly, Jeff Strnad argnes that the advantage to the rich may be defensible as a bargain under which greater benefit is given to the rich for contributions to encourage their funding goods of general benefit. Strnad, supra note 27, at 276. 


\section{B. Refinements}

\section{The Pleasures of Giving}

Economic models favoring a system of tax-free giving to charity tend to be blind to a major component of utility in a system of voluntary giving: the pleasure that people get from voluntary giving which they would lose under a system that forced them to pay for public goods through the market or a tax. Economists are sensitive to transaction costs, but they tend to overlook what may be called transaction gains. ${ }^{41}$

That voluntary giving may be a source of satisfaction is clearest in the case of philanthropy. (Of course, not only philanthropists enjoy acting charitably. Although we do not know exactly to what extent altruistic behavior is so motivated, ${ }^{42}$ undoubtedly many people take great satisfaction in acting charitably.) $\mathrm{A}$ gift of $\$ 5,000,000$ by a patron to a museum, for example, is far in excess of the price she would be willing to pay to visit the museum in the course of a lifetime. This sort of gift is impossible to account for within the Hochman and Rodgers (or more generally a Lindahl) analysis, because that analysis posits that each individual is willing to pay for a collective good only

41 For a stimulating discussion of how accounting for these utilities might influence the analysis of the efficiency of other political-economic arrangements, see A. Hirschman, Essays in Trespassing: Economics to Politics and Beyond 214-19 (1981).

It has been suggested that altruistic gifts deserve preference under an income tax because they are doubly satisfying. Friedman, Does Altruism Produce Efficient Outcomes? Marshall versus Kaldor, $17 \mathrm{~J}$. Legal Stud. 1, 8-12 (1988). The argument is that taxing altruism is doubly bad because it reduces the welfare both of the recipient and of the donor. It derives from the theory of optimal taxation which decries the "deadweight loss" of a tax. See Sandmo, Optimal Taxation: An Introduction to the Literature, $6 \mathrm{~J}$. Pub. Econ. 37 (1976). For example, although $A$ may get $\$ 1.19$ pleasure from an apple selling for $\$ 1.00$, she will refuse to buy it if there is a sales tax of 20 percent or greater. The $\$ 0.19$ is a deadweight loss from the tax. $A$ is denied the pleasure of eating the apple and nothing is gained (no tax is raised). Taxing $A$ 's gift of an apple to $B$ has that same effect ( $A$ will not give $B$ the apple unless $B$ receives $\$ 1.20$ or more pleasure if the gift tax is 20 percent), and it also denies $B$ the pleasure of eating the apple. The deadweight loss is multiphed because the taxed behavior benefits two people.

The problem thus identified is not unique to taxing altruistic behavior. It exists whenever we tax behavior supporting collective goods because the tax then falls on someone in addition to the actor. For example, if $A$ enjoys watching $B$ eat an apple, taxing $B$ 's purchase of an apple deprives $A$ pleasure just as much as does taxing $A$ 's gift of an apple to $B$. Or, if we tax $A$ 's gift to public television (which $A$ makes for entirely selfish reasons), the tax bears not only on $A$ but also on every other viewer.

42 See infra notes $120-137$ and accompanying text. 
what it is worth to her. ${ }^{43}$ Philanthropists pay far more. This does not mean that philanthropists are acting other than as rational, egoistic, pleasure maximizers (or as other than economic creatures); they may take pleasure in the status accorded philanthropists or they may find joy in domg good. ${ }^{44}$

Because of the joys of giving, philanthropy (and other forms of charity) may be a "supraoptimal" solution to funding collective goods. ${ }^{45}$ It makes philanthropists happier, because undoubtedly they enjoy giving voluntarily more than they would enjoy paying similar amounts in taxes or in user fees. Their philanthropy also benefits the rest of us. Philanthropists give more than they would pay for a good under a pricing regime, so that the rest of us inay pay less for the good while still enjoying it at an optimal level. Philanthropists, in essence, redistribute resources to us in return for our respect or their own self-

43 See supra notes 23-24 and accompanying text.

44 One study finds that people who make sizeable gifts generally say they give for the same reasons as other people, though, as one would expect, high-income donors complain much more often that they give because charities "keep bothering me." Morgan, Dye, \& Hybels, Results From Two National Surveys of Philanthropic Activity, 2 Research Papers, supra note 1, at 157, 198-201. High-income donors more often think that people are sensitive to how much others give, but, iromically, they also less often think that publicizing donors stimulates giving. Id. at 203-04. Small (under $\$ 100$ ) and big (over $\$ 5,000$ ) donors most often say that they gave because they got some benefit in return, but even among these groups less than 20 percent of respondents so report. Id. at 205. Donors in different income groups differ most in the charities to which they give. As a percentage of total giving, wealthier individuals give far less to rehigious organizations (those earning between $\$ 10,000$ and $\$ 19,999$ give 67 percent to religion, while those earning $\$ 500,000$ or more give 9 percent) and far more to higher education (for the same groups the respective percentages are 1 percent and 24 percent). Id. at 208. There is much anecdotal evidence that philanthropy is status driven. Large donors, for example, tend to fund capital improvements because of their pernanence and visibility. See A. Feld, M. O'Hare, \& J. Schuster, Patrons Despite Themselves: Taxpayers and Arts Policy 136, 140 (1983). The honor accorded donors has been held sufficient consideration to enforce donative promises under the bargam theory of contracts. See Allegheny College v. Nat'l Chautauqua County Bank of Jamestown, 246 N.Y. 369, 159 N.E. 173 (1927) (Cardozo, J.).

45 The prestige or pleasure people get from acting charitably comes at little cost to society (other than the cost of a deduction). Mark Kelman has argucd to the contrary, emphasizing that real costs in time and resources are incurred by honoring philanthropists. Kelman, supra note 2 , at $850-51$. But the cost of a testimouial dinner, name plaque, or other tangible honor is likely to be trivial in relation to the size of the gift. Certainly whatever costs are entailed will be far smaller than the costs of collecting similar sums as taxes (the cost of the taxing authority, private tax advisors, and whatever evasive actions people take). Kelman also claims that "looking altruistic" is, itself, a scarce resource. Id. at 880 . If by "looking altruistic" he means being respected for acting charitably, one would guess that we are far from exhausting our capacity for respect. 
respect. $^{46}$

Circumstances may arise in which the pleasures of giving induce people to overinvest in goods. If a good is already funded at close to an optimal level, gifts made for the pleasure or prestige of giving will allocate excessive resources to it. Overbuilding on campuses because of a donor "edifice complex" is an example of this. Another example, not involving philanthropy per se, is the tendency of people to commit excessive resources to highly publicized causes, e.g., the gifts showered on Jessica McClure, the girl rescued from a well in Midland, Texas. ${ }^{47}$ For most charities, however, the greater risk is likely to be underfunding because of freeriding. Philanthropy im particular, but also all forms of charity which confer special rewards on donors, make up some of that difference.

The pleasure people take in giving may be critical to the argument for a deduction. As we have seen, tax-free voluntary giving is a terribly imperfect way to fund collective goods because it can shift only a small part of the cost of a good to freeriders. The pleasure people get from charity makes this imperfection more tolerable. Donors may prefer a system in which charities are underfunded, and they pay a disproportionate share of the cost, because of the pleasure (and influence) they get from a voluntary system.

Another advantage claimed for a voluntary system of giving over direct government support is less siguificant. Some argue that private giving promotes diversity and experimentation in funding collective goods. ${ }^{48}$ What they celebrate is different from the ability of charities to respond to heterogeneous demands for collective goods; ${ }^{49}$ these commentators prize diversity more as a value in itself. Private giving is preferred because it runs counter to the preferences of majorities or

46 Richard Titmuss has found that a voluntary system for obtaining blood produced more blood of a higher quality than a market system in which people were paid for their blood. $R$. Titmuss, The Gift Relationship (1971).

47 See generally N.Y. Times, Oct. 16, 1987 at A12, col. 2 (discussing the Jessica McLure episode).

48 Simon, Charity and Dynasty Under the Federal Tax System, in The Economics of Nonprofit Institutions, supra note 15 at 253-59; cf. Galston, Public Policy Constraints on Charitable Organizations, 3 Va. Tax Rev. 291, 309 (1984) (advocating "two-tiered exemption doctrine, which clearly separates questions of charitable or educational value from public policy considerations," on grounds that such an approach is "more consistent with ... our commitment to cultural, moral and political pluralism").

49 See supra note 21 and accompanying text. 
other influential groups, and so may allocate resources to activities presently undervalued but which turn out to be socially beneficial. Sometimes the rewards are concrete. The early work on Jonas Salk's polio vaccine, for example, was funded privately. ${ }^{50}$ Sometimes the rewards are less tangible. Private charity is celebrated im the arts, for example, on the ground that it funds new forms of expression which enrich our culture.

That it promotes experimentation or novelty is not a compelhing reason for preferring tax-free treatment for private giving over other strategies for funding goods. First, this advantage of private charity, if it exists at all, is relative only to government provision of a good. If a good may be provided through the market, that mechanism promotes novelty and experimentation just as well. ${ }^{51}$ Second, the advantages of private charity over government in this regard are speculative and may be outweighed by attendant costs. In the arts, for example, private donors tend to be no more adventurous than government commissions. Managers of artistic enterprises in fact complain that to win private support they must stick to a traditional repertory or cater to a small class of wealthy donors. ${ }^{52}$ Finally, permitting individuals to choose what goods to support may lead to waste. In medicine, for example, people support well-pubhicized causes without regard to the relative needs of other causes or the likelihood that research in any particular field will pay off. ${ }^{53}$

\section{Privileged Groups}

Even though a charity benefits everyone in society, it may not deserve support through a contributions deduction. This is implicit in Hochman and Rodgers's model. Because the price people pay for a good is fixed by the incremental value they place on the last unit of a good provided, people satisfied at low levels of funding for a good for whom the last unit is of disutility should pay nothmg for it. In the example of the park above, if $A$ and $B$ place no value on a third unit of the park, and $C$ values it at $\$ 3.00$ (the unit's cost), then under a Lin-

\footnotetext{
so Simon, supra note 48 , at 254.

51 See infra notes $179-182$ and accompanying text (discussing public television),

52 A. Feld, M. O'Hare, \& J. Schuster, supra note 44, at 122-24, 161, 164-66.

53 Brannon \& Strnad, Alternative Approaches to Encouraging Philanthropic Activities, 4 Research Papers, supra note 1, at 2361, 2374-77.
} 
dahl solution, $A$ and $B$ would pay nothing and $C$ would pay $\$ 9.00$ for a three-unit park.

This is one example of a phenomenon recently identified in work on problems of collective action. Groups benefiting from a good in these circumstances are said to be "privileged."54 A group is privileged when one or more meinbers ${ }^{55}$ ( $C$ in the park example) get enough satisfaction from a good to induce thein to provide it for the entire group. For example, Howard Hughes reportedly once bought a Las Vegas television station to broadcast western and aviation movies through the night so that he could watch them. ${ }^{56}$ Las Vegas insomniacs with a taste for such movies were a privileged group.

The group of park users is privileged because of asymmetries in benefits: $C$ alone pays for the park because he alone values the last unit. A group nray also be privileged if a collective good is a "lumpy" or "step" good even if benefits are symmetrical. For example, suppose I share a hallway with ten colleagues. Each of us gets $\$ 50$ worth of satisfaction from one print on the wall, $\$ 60$ worth from two, and $\$ 30$ worth froin three (clutter inakes the prints less attractive). Each print costs $\$ 50$. Art is a lumpy or step good because of the indivisibility of prints. In this case a Lindahl solution is unattainable because there is no point at which the sum of inarginal benefits froin the prints equals their inarginal cost. The closest my colleagues and I can coine to a Lindahl solution is the last uinit of the good where the sum of our marginal benefits from that unit is equal to or greater than its inarginal cost. Thus, we should hang the second print $(10 \times \$ 10>\$ 50)$, but not the third $(10 \times-\$ 30<\$ 50)$. The group is privileged because at the optinum any five of us have sufficient incentive to hang the second print.

The phenomenon of privileged groups is important. It illustrates why demonstrating that a charity (or even the last unit of spending on a charity) benefits all of society does not by itself establish the need for

54 R. Hardin, Collective Action 20 (1982) (citing M. Olson, The Logic of Collective Action $23,49-50$ (1965)).

55 The formal definition speaks of one party funding the good. Id. This Article, however, uses the term more loosely to include situations in which a relatively small, closely-knit group is the primary beneficiary of a collective good which indirectly benefits the rest of society. When that group has the ability to overcome freerider problems among themselves and sufficient desire to fund the good at the level optimal for society generally, the rest of society may be said to be privileged with respect to that good.

56 People, Time, Apr. 8, 1974, at 42. 
a deduction as a subsidy. Especially in the case of churches, schools, and other charities that primarily benefit a small group and secondarily benefit society generally, attention must be paid to the possibility that the small group has sufficient incentive to fund the good at an optimal level without a deduction for its payments.

\section{Taxing the Disinterested}

Despite the possibility of privileged groups, the preceding discussion has presented a fairly persuasive case for a charitable deduction. A deduction enables groups to fund the collective goods they want at a small cost to society, while preserving the pleasures of giving. There is, however, a darker aspect to this picture: Some people lose because of a deduction. No matter how worthy the cause, some will complain that they do not want to help support a charity indirectly through a deduction. Some may dislike the Salvation Army because they believe that the poor are lazy and deserve to suffer in poverty. Some may oppose the Red Cross because they think it paternalistic. Seventh-day Adventists may oppose medical charities. Libertarians may oppose any scheme of taxing them for collective goods because they beheve it is theft. These people are the radically disinterested. Almost certainly, others will desire a low level of funding for a charity but get no benefit from additional expenditures on it resulting from a deduction. These people may be called the marginally disinterested.

The presence of radically or inarginally disinterested parties ensures that a deduction never can be justified as a Pareto iinprovement, that is, as a policy that inakes some people better off and no one worse off. The argument for a deduction in the real world must appeal to a different notion of efficiency, that of Kaldor-Hicks. This criterion for the efficiency of a social policy asks whether the welfare gains from its adoption more than offset the welfare losses-or, put differently, whether winners under the policy gain enough in dollars to pay off the losers and still be ahead. (Actual payment is not required.) If winners win more than losers lose, a policy is a KaldorHicks improvement. If no further improvement is possible a position is Kaldor-Hicks efficient. ${ }^{57}$ A contributions deduction is a Kaldor-

57 For an explanation of Kaldor-Hicks, see Coleman, Efficiency, Utility, and Wealth Maximization, 8 Hofstra L. Rev. 509 (1980). Richard Markovits explains that to control for wealth effects one should compare the amounts winners would pay to avoid losing (being left in the status quo) with the amounts losers would have to lose to be left as badly off as they are 
Hicks improvement if the dollar gain to beneficiaries from moving towards an optimal level of funding for the charity is greater than the dollar loss to the disinterested. (Dollar gain is the amount winners would pay to secure the movement of resources; dollar loss is the amount losers would pay to prevent it.) For example, a deduction of gifts to medical charities imight be justified on this ground if the cost to Christian Scientists (a few dollars per household if we disregard possible moral outrage) is less than the gain to users, donors, and freeriders from moving toward an optimal level of funding of such charities by spreading its cost.

Enormous problems exist in justifying a deduction on the ground that, although it hurts some people, it helps others more. One may reject the ethical assumption underlying Kaldor-Hicks that it is proper to injure one person if doing so benefits another person more. The standard, moreover, is difficult to apply because who wins and who loses from a policy, and by how much, is hard to determine. Even if we had rehable data on the effects of a deduction, the analysis requires controversial interpersonal utility comparisons. ${ }^{58}$ Indeed, some would assert that the shift from Pareto to Kaldor-Hicks deprives the subsidy argument of moral legitimacy. They argue that while the Pareto standard may be justified on utilitarian grounds or even on hiberal theories of consent, the Kaldor-Hicks standard may not. ${ }^{59}$

No effort is made here to resolve the ethical question whether it is right to take from one person to enrich others more. Most people probably think this appropriate in some situations (e.g., drafting young men to fight Hitler). Certainly, Kaldor-Hicks is a commonly accepted standard of efficiency. ${ }^{60}$ Some empirical problems in apply-

in the status quo. Markovits, Legal Analysis and the Economic Analysis of Allocative Efficiency, 8 Hofstra L. Rev. 811, 816-19 (1980). This refinement controls for the fact that, absent adoption of the policy, winners and losers would have different levels of wealth and so would value things differently than they do once the policy is adopted. Markovits notes that this reformulation makes policies that redistribute resources to the poor more attractive by accounting for the greater stakes to the poor of additional dollars when they are poor (and the lesser stakes to the rich when they are rich). Id. at 821-22.

58 See Coleman, supra note 57, at 519-20 (discussing difficulties of cardinal interpersonal utility comparisons).

59 See J. Coleman, Markets, Morals and the Law x-xii (1988).

60 See W. Landes \& R. Posner, The Economic Structure of Tort Law 17 (1987) ("The use of efficiency in the Kaldor-Hicks sense is an ancient and honorable guide to social policy."). 
ing it are examined in Part IV.

Abandoning the rigid Pareto criteria that underpin the Hochman and Rodgers and Lindahl analyses niakes it possible to account for the redistributive value of charitable giving. A benefits-pricing nıodel requires people to support a good only to the extent they benefit from it. Thus, the case for supporting the Salvation Army (or other prograins aiding the needy) turns on the benefits the wealthy receive from helping the needy and not on the iniprovement in the welfare of the needy. Although inany econonists adopt this view, ${ }^{61}$ as I learned in presenting a version of this Article in a colloquium, niany noneconomists (and sonie economists) think it is crazy. Many think, for example, that it is desirable for a rich man to give $\$ 5.00$ for a nuuch-needed meal to a poor inan, even though the rich nian cares not a whit for the poor man's pleasure and no one else knows of the gift. Aside fron the "external" benefits of the gift, the fact reniains that the poor man has been inade happier, and his happiness is enough to coniniend the gift. Modifying the subsidy theory to allow benefits to the needy to offset costs incurred by the relatively well-off makes it possible to account for the unpurchased pleasure of the pauper.

\section{ANDREWS REVISITED}

William Andrews wrote Personal Deductions in an Ideal Income Tax because he found the criticisms of the subsidy theory, particularly criticism of its upside-down effect, to be "devastating."62 $\mathrm{He}$ tries to inake a better case for the deduction based on "the intrinsic objectives of the [income] tax." "63 His theory inerits close attention. Although it has been harshly criticized by some, ${ }^{64}$ Andrews's theory is now accepted by many, ${ }^{65}$ and even those who persist in justifying a deduction as a subsidy think Andrews offers a very different argument for a deduction. ${ }^{66}$

61 See M. Friedman, Capitalism and Freedom 191 (1962); Hochman \& Rodgers, Pareto Optimal Redistribution, 59 Am. Econ. Rev. 542 (1969).

62 Andrews, supra note 6, at 311.

63 Id. at 312.

64 See Kelman, supra note 2.

65 See Turnier, Personal Deductions and Tax Reform: The High Road and the Low Road, 31 Vill. L. Rev. 1703, 1708-9 (1986).

66 C. Clotfelter, supra note 3 , at $279-80$. 
Andrews posits that incoine should be defined in an "ideal" tax as amounts consumed by a person in the taxable period plus accretions in her wealth over the period. ${ }^{67}$ (The definition of incoine is that popularized in this country by Henry Simons and Robert Haig. It is widely accepted by lawyers. ${ }^{68}$ ) From a literal understanding of this definition, Andrews reasons that gifts to charity and medical expenses should not count as consumption (and so not figured in taxable income) because of two fundamental purposes of the income tax. The primary one is to "reduce private consumption and accumulation in order to free resources for public use."69 Secondarily, the tax is to effect this reduction of private consumption (and also a redistribution of wealtli) "in some kind of uniform (though graduated) relationship to the amount of consuinption and accuinulation people otherwise would enjoy."70 Medical expenses should be deductible, if these are the purposes of the income tax, because people who incur thein tend to be worse off than their neighbors; they "reflect differences in need rather than choices among gratifications," and so should not be treated as items of consumption. ${ }^{71}$

Gifts to charity should not be considered consumption, according to Andrews, because they do not divert resources to private use. The benefits people derive from giving to charity generally are, in his words, "common goods," in that "their enjoyment is not limited exclusively or even primarily to those who pay for them," and that "one person's enjoyinent of thein will not directly impair another's enjoyment."72 So he says of the pleasures of giving that "[t]he satisfaction one gets from making a cliaritable contribution is ... like a great many of the rest of life's best satisfactions which people can enjoy without diverting economic resources away from other people and whicl we do not try to take into account in assessing income taxes."73 The heart of the idea is that an income tax should treat pleasures people gain differently without diminishing society's store of scarce goods or services. The assumption underlying this difference of

67 Andrews, supra note 6, at 320-25.

68 See Goode, The Economic Definition of Income, in Comprehensive Income Taxation 1

(J. Pechman ed. 1977).

69 Andrews, supra note 6, at 313 .

70 Id. at 326.

7 Id. at 336.

72 Id. at 357-58.

73 Id. at 356. 
treatment is that the income tax should function as a penalty for diminishing society's resources, that is, as a mechanism "to divert economic resources from personal consumption and accumulation" to governmental use. ${ }^{74}$

There are three problems with Andrews's argument. First, Andrews errs in saying that reasons "intrinsic" to the income tax justify the deduction. This is probably just an unfortunate choice of words, for it is clear that Andrews recognizes that the definition of income (as consumption plus accumulation) depends on administrative, economic, or distributional concerns extrinsic to tax law. Second, all Andrews really does is to repackage the arguments for subsidizing charities. The collective benefits of charities that make them worthy of public subsidy are, for Andrews, a reason for excluding from the definition of income resources people comint to charity and the benefits they derive from charity. Third, Andrews's theory fails at the critical task of defiming what collective goods should be excluded from income. In sum, Andrews's arguments in favor of the contributions deduction ultimately add little to the subsidy justification of the deduction. As discussed in the next Part of this Article, however, his argument for deducting medical expenses is more useful, because it suggests that there may be a distributional value implicit in the Haig-Simons definition of income (some call it the ability-to-pay principle) that might justify deducting some charitable contributions. ${ }^{75}$

\section{A. The Internal Logic of the Income Tax}

The first point addresses the way Andrews characterizes (and other people perceive) the arguments he makes for a deduction. Andrews insists that adequate reasons for a deduction are "intrinsic" to the income $\operatorname{tax}^{76}$ If this is correct, attempts to base the deduction on policies extrinsic to the tax, such as the argument for subsidizing

74 Id. at 325.

75 Joseph Dodge would make the same point differently. He says that Andrews appeals to the notion embedded in Haig-Simons that people should be taxed according to their ability to pay. Andrews errs, according to Dodge, in insisting that a medical expense deduction is intrinsic to a consumption-based tax, because what he is actually saying is that a deduction is consistent with the ability-to-pay principle, which is intrinsic to the Haig-Simons definition of income.

76 See Andrews, supra note 6, at 314-15. 
charities, are superfluous. Other scholars have taken Andrews at his word on this. If Andrews is right, one has said, a deduction "becomes 'a matter of principle' and there remains hittle to discuss concerning the proper tax treatment of charitable giving." 77

Andrews is not (or at least should not be) claiming that a deduction for contributions follows logically from the choice to tax mcome. It is useful to put his article im its historical context. Andrews is respondimg to tax expenditure theory, which holds that most personal deductions should be considered equivalent to programs of government expenditure. ${ }^{78}$ Andrews argues, quite correctly, that many deductions or exclusions may be justified by concerns other than those that may motivate a program of government expenditure. A medical expense deduction, for example, might be justified by the principle that people should bear the burden of the tax in relation to their relative well-being.

To say that personal deductions may be justified by reasons other than those that motivate programs of government expenditure, however, is not equivalent to saying that these other reasons for deductions are "imtrinsic" to the tax or that they follow inevitably from the clioice to tax income. They are just policies-like the distributional or economic pohicies favoring a subsidy for charities-that we may take into account in designing the tax.

Andrews recoguizes that little follows necessarily from the choice to tax imcome. To say that we want to tax "income"-or even HaigSimons's consumption plus accumulation-only sets the broadest paraineters on the debate about what sliould be taxed. ${ }^{79}$ The concept

77 C. Clotfelter, supra note 3 , at 280 , quoting Break, Charitable Contributions Under the Federal Individual Income Tax: Alternative Policy Options, 3 Research Papers, supra note 1, at $1521,1530$.

78 Andrews, supra note 6, at 309-10.

79 This is evident from the debate over what should count as consumption. Some insist that the consumption component of Haig-Simons should include all personal receipts spent on ends other than producing income. See S. Surrey \& P. McDaniel, Tax Expenditures 205-06 (1985). This approach would include in income not only charitable gifts, but also casualty losses and medical expenses. Id.

Simons's stance on this issue is not clear. Simons wrote that "[p]ersonal income connotes, broadly, the exercise of control over the use of society's scarce resources," but also that "[c]onsumption as a quantity denotes the value of rights exercised in a certain way (in destruction of economic goods)." H. Simons, Personal Income Taxation 49-50 (1938). If it is control over resources that counts, then transfers to charity should be taxed to the donor. If what is significant is whether the taxpayer has destroyed (consumed) resources, then, as 
of consumption is so ambiguous, and infinitely expandable, ${ }^{80}$ that, im Andrews's own words, the actual definition of mcome nust come fron1 weighing "competing considerations of fairness and practicality" and "creative elaboration to effectuate the practical implenientation of the purposes of the tax." 82

A provision may be "intrinsic" to the inconie tax in a weaker sense. It is frequently argued that the way one activity is taxed under the Internal Revenue Code necessitates taxing a related activity similarly. Because Andrews and other scholars often justify (or criticize) a deduction for contributions by reference to other provisions we must pause briefly to consider these arguments.

Examples abound. Andrews argues that the fact we do not tax people who donate services to charity on the imputed value of their time suggests "a more basic principle" that supports a deduction of gifts of money or property. ${ }^{83}$ Another scholar has asserted that a deduction follows logically from the choice to exempt the nicome of charities

Andrews argues, gifts to charity perhaps should be deductible when a donor's benefit from the use of resources does not diminish the benefits available to others.

There are suggestions in his work that Simons opposed a contributions deduction. $\mathrm{He}$ thought personal gifts (which pose an analogous problem) should be included in the income of the donor, as well as the donee, because giving was pleasurable and indistinguishable from other forms of consumption. Id. at 57-58, 125-47. In the course of discussing gifts, Simons seems to touch on the issue of charity:

There are consumption incidents to charity and generosity which are meagerly paralleled in the payment of debts. The person who can and does support his destitute relatives is surely better off himself on that account than one who, helpless, must endure the spectacle of their distress .... After all, we are faced with an excessive inequality of economic power and with a kind of inequality which bears no significant relation to the inequalities in needs. So, it may suffice to attack cconomic inequality directly, to dininish it as it stands, without trying much to twist it toward a kind of inequality which our sentiments may approve; otherwise, our main objective may be lost in the pursuit of ill-defined and less important ends. The income tax is not a proper vehicle for sumptuary legislation. Besides, there is soinething wrong with a system which gives great power to a few people, no nuatter how they use that power. If a man devotes practically all of his million-dollar income to the support of the niost worthy causes, the question remains of whether anyone should be permitted so much power.

Id. at 140-41.

80 See Andrews, supra note 6, at 321.

81 Id. at 323.

82 Id. at 324.

83 Id. at 353. Much of Andrews's essay is concerned with analogous tax provisions that support or contradict his theory. Id. at 347-48, 352-54 (comparison to nontaxation of giving time); id. 348-51 (nontaxation of personal gifts); id. 364-66 (taxation of political contributions). 
from tax. ${ }^{84}$ Similar arguments are made against a deduction. For example, Mark Kelman argues that the invalidity of Andrews's principle that free goods are not taxed is demonstrated by the fact that airline employees flying in open seats sometines are taxed (sometimes they are not $^{85}$ ) or the fact that people who pay a inonopolist's surcharge for goods are not allowed deductions. ${ }^{86}$

Little or no weight should be given to these arguments. In most cases it is likely that the provision cited as analogous is justified by reasons unique to the activity it addresses, and, even where two provisions seem to raise similar issues, to tie the fate of one to another merely shifts the debate to the propriety of the latter. Consider Andrews's argument that our choice not to tax people who give time to charity suggests a principle requiring that we not tax people who give money to charity. It is possible that we do not tax people who give time to charity for reasons having nothing to do with a deduction for contributions. We may do it because we cannot value donated time, or, as Mark Kelman suggests, because we do not want the tax to force people into market exchanges. ${ }^{87}$ And, even if we thought they posed the same issue, hinking a deduction for cash gifts to the choice not to tax people who give time to charity only raises the question of why we do not tax volunteers. ${ }^{88}$

If internal coinparisons deserve any weight it is because of a concern that unlike treatment of like activities is inequitable and inefficient, and denying a deduction for cash gifts to charity while not taxing people who give time to charity arguably is both. It is inequitable because it disadvantages people without skills useful to charities who can do good only through money donations. It is inefficient

84 See McNulty, Public Policy and Private Charity: A Tax Policy Perspective, 3 Va. Tax Rev. 229, 232-33 (1984).

85 Section 132(b) now excludes this benefit as a "no-additional-cost service" so long as it is made available to all employees of the airline on a nondiscriminatory basis. I.R.C. $\S 132(\mathrm{~b})$ (Supp. IV 1986).

86 See Kelınan, supra note 2, at $845-46$.

87 See id. at 838-44.

88 At least one provision in the Code seems to follow from Andrews's principle that free goods should not be taxed. See I.R.C. $\$ 132$ (b) (Supp. IV 1986) (excluding no additional cost fringe benefits, e.g., letting airline employees fly in unused seats, from income). Nevertheless, it is difficult to sec how one anomalous and narrow provision lends much credence to Andrews's general principle. 
because it encourages people who wish to give to charity to provide in-kind services for which they may not be well suited.

As a general matter, these concerns may not be compelling insofar as any mequity or inefficiency results from not taxing imputed income (which people derive by using their skills or resources for their own benefit). Administrative realities (e.g., valuation and enforcement problems) preclude taxing most imputed income. Treating nonimputed income equally in order to avoid inequity or overinvestment in the untaxed activity would make all mcome untaxable. Thus, it is inequitable and mefficient to tax wages people pay to carpenters for home repairs while people who repair their own homes go untaxed. This unequal treatment discriminates against inept woodworkers and encourages them (foolishly) to take up tools. The same objections may be raised against taxing the wage earner while not taxing the idler's leisure, because doing so favors those of idle pleasures and encourages loafing. We tolerate these effects because the loafer and home repairer cannot feasibly be taxed and the wage earner cannot be allowed to avoid the tax.

Tymg the treatment of cash donors to the treatment of volunteers is particularly indefensible. It is estimated that the value of volunteer labor services is one-fifth to two-fifths the value of cash contributions given to charity. ${ }^{89}$. It is perverse to msist that the treatment of the lesser should determme how we treat the greater. Further, it is generally the case "that the giving of time and money go together." 90 This fact weakens the equitable argument because the people who are benefited by not including in mcome the imputed returns of donated services are largely the same people who will be benefited by a deduction for cash gifts.

Everything said to this point only puts Andrews's theory in proper context. The deduction for contributions does not follow logically, or necessarily, from the choice to tax income, and it is not required by other provisions in the Internal Revenue Code. The deduction must be judged on the basis of its fairness, efficiency, or other normative or admimistrative virtues.

89 Weisbrod and Long, The Size of the Voluntary Nonprofit Sector: Concepts and Measures, 1 Research Papers, supra note 1, at 339, 342-43.

90 Morgan, Dye, and Hybels, supra note 44, at 173. 


\section{B. A Subsidy by Any Other Name}

Much of Andrews's argument for allowing deductions for contributions to charity shares a premise with the argument for a deduction as a subsidy: the fact that charities provide collective goods. Andrews frames his argument a little differently-in terms of consistency with the purposes of the income tax. The purpose of the tax, for Andrews, is to divert resources from private consumption to public. ${ }^{91}$ Thus, gifts to charities (and the benefits derived from them) need not be taxed because they are items of public, not private consumption..$^{92}$ That is, by giving to charity, people do voluntarily what a tax would coerce them to do, and so there is no reason to tax this behavior. This justification merely flips the argument for subsidizing charities on its head. Economists would provide a deduction to encourage people to do voluntarily what we would otherwise have to coerce them to do (i.e., fund collective goods).

Similarities between Andrews's theory and the subsidy theory crop up throughout his analysis. The concepts invoked are the same. The qualities of publicness (or collectiveness) and nonpreclusiveness invoked by Andrews ${ }^{93}$ are similar to the qualities relied upon by proponents of the subsidy theory. Andrews echoes subsidy theorists in arguing that it is inadvisable to deny contributors a deduction because doing so would raise the price of giving and tempt some donors to freeride, ${ }^{94}$ and in asserting that charities deserve support through a deduction because charities provide public goods that government would otherwise have to fund directly if they are to be maintained at optimal levels. ${ }^{95}$

As striking as is Andrews's rehiance on elements of the subsidy theory is the fact that the other reasons he gives for a deduction are not

91 See Andrews, supra note 6, at 313. Denying a deduction for cash gifts may still be inefficient if donors can readily substitute volunteer work for giving money or property. There is no evidence, however, that current tax law has had such an effect.

92 See id. at 356 (characterizing taxable consumption as the "utilization of economic resources ... for private consumption within the taxpayer's household") (emphasis added).

93 See id. at 314-15 (consumption should not include "collective goods whose enjoyment is nonpreclusive ...."); id. at 357 ("Almost all charitable organizations ... produce something in the nature of common or social goods or services."); id. at 358 ("[I]t is typically the case that the benefits produced by a charitable organization are free goods in the sense that one person's enjoyment of them will not directly impair another's enjoyment.").

94 See id. at 361-62.

95 See id. at 370. 
credible, at least in the way he states them. He notes, for example, that one rationale for disallowing a deduction is that we might tax the donor as a proxy for the beneficiary. ${ }^{96}$ But, Andrews responds, the tax on the donor would be at the wrong rate (that of the donor rather than the beneficiary), and typically this rate would be too high because most donations are probably made by the well-off to charities that benefit the less well-off. ${ }^{97}$

Andrews is wrong if the economists are right and people give to these charities because they enjoy their services. Then by her gift to a museum or church a donor discloses the minimum value she sets on the benefit she receives. There should be no objection to including at least that amount in her income. Further, because she is being taxed on her benefit from the charity, her marginal rate is appropriate. In other words, by taxing the donor we are taxing the beneficiary, and there is no discrepancy in rates. To defend a deduction against this attack, Andrews would have to argue that people do not give to these charities because they enjoy their services or take pleasure in giving. Although Andrews is aware of this egoistic interpretation of giving, ${ }^{98}$ he does not argue against it. Later we will see that if we conceive of giving as nonegoistic, or as self-abnegating, a deduction may be justified more straightforwardly. ${ }^{99}$

Andrews also tries to defend a deduction on the equitable ground that donors are made relatively worse off by supporting goods everyone enjoys. ${ }^{100}$ Donors are made worse off relative to freeriders, he argues, who benefit from that same service without paying for it. This rationale for a deduction is considerably weakened if a charity benefits only a few people. If public television benefits only a few people, for example, contributors who support it and commensurately benefit from it are not made worse off by their gifts relative to the many nonviewers. Donors are made worse off relative to most people only if freeriding beneficiaries outnumber donors and disinterested parties combined.

In any event, this argument for a deduction is better expressed in terms of the subsidy theory. It emphasizes the fairness, rather than

\footnotetext{
96 See id. at 360.

97 See id. at $360-61$.

98 See id. at $355-56$

99 See infra notes 110-137 and accoinpanying text.

100 Andrews, supra note 6, at 368.
} 
the efficiency, of spreading the cost of collective goods across all users. The more rigorous analysis of the subsidy theory is preferable because it avoids Andrews's false (if imphicit) assumption that the amount deducted by donors equals the difference in the relative well-bemg between donors and freeriders. This equality will obtain only if the surplus value donors receive from charities (i.e., the excess value over the after-tax cost of gifts) equals the value freeriders receive from charities. For example, if $A$ gives $\$ 100$ to charity and is in a thirtythree percent bracket, a deduction reduces her cost of giving to $\$ 67$. Deducting will make $A$ exactly as well-off as the freerider $B$ only if $A$ values the charity $\$ 67$ more than $B$, who still benefits from the charity while paying nothing. If $A$ values the charity more, a deduction overcompensates her; if she values it less, it undercompensates. Andrews's emphasis on the inequities between freeriders and donors who are not given a deduction is misplaced, because, although allowing donors to deduct will improve their relative lot, there is no assurance that with a deduction donors will be equally well-off.

Andrews also argues that the pleasures of giving should not be taxed because they are free. ${ }^{101}$ There is no reason to tax the pleasure of giving food to a poor man, because it is free. The food is there to be consumed by the pauper. Andrews makes this point most strongly when talking about alms to the poor. The pleasure people get from giving to other charities (e.g., churches or public television) entail the destruction of resources. If gifts to these charities are "free," it is only in the sense that "one person's enjoyment of . . . [the goods provided by charities] will not directly impair another's enjoyment." 102

The following section will question whether this concept of freeness has any meaning. There is a more basic question: Why should we care if a pleasure is free? The essence of voluntary exchange is that it inakes both parties better off (by their hights). If Andrews is right, then the gains from trade should not be taxed because they are free. They come, as if froin thin air, because two parties set different values on the commodities exchanged. But, of course, it is that element of profit from exchange that is exactly what the tax usually tries to

101 See id. at $356,358$.

102 Id. at 358. 
reach. ${ }^{103}$ From this perspective egoistic giving may be called a profitable transaction. The donor (who seeks nothing in return) derives at least a dollar's worth of satisfaction when she gives a dollar to the pauper; the pauper gets his dollar's worth when he spends it. If we want to tax the "profit" on the exchange, we should tax both the donor and the pauper.

\section{What is Free?}

Andrews's theory finally is not very useful because it offers no way to tell what should count as charity. He takes a characteristic of expenditures on charity-they benefit the community as well as donors-as a reason for making them deductible. But, of course, many other individual expenditures benefit other people. Examples include school tuition, the expense of painting one's house, fees paid for admission to public events, or, indeed, any amounts paid for goods with diminishing marginal costs (each purchase makes the good cheaper to everyone else). And what of labor unions, business leagues, cooperatives, beneficial associations, or other clubs? ${ }^{104}$ Fees paid to them support a good shared in common by members of the club (and freeriders). Andrews's theory cannot distinguish between charity and other personal expenditures with positive externalities.

Andrews's difficulty with this point is exemplified by his failure to grapple with the problem of how widely shared the benefits from an organization must be before expenditures on it are sufficiently public and nonpreclusive that it may be deemed a charity. He suggests in places that enjoyment of a good is nonpreclusive so long as its benefits extend beyond the taxpayer's household, ${ }^{105}$ which he extends to include friends, ${ }^{106}$ but he also says that for a good to be public its benefits must be "made available as a free good for shared use within a reasonably wide community of persons." 107 To draw the line at the household would make every club or football game a charity, and to

103 Cf. Lane, A Theory of the Tax Base: The Exchange Model, 3 Am. J. Tax Pol'y 1, 111 (1984) (arguing for model according to which "productive exchange ... [is] the major criterion of aggregate taxability").

104 Many of these entities are tax-exempt, see I.R.C. $\S 501$ (c) (Supp. IV 1986), but fees paid to them are not deductible under $\S 170$.

105 See Andrews, supra note 6, at 364, 369.

106 Id. at 351.

107 Id. at 369. 
insist upon benefit to a "reasonably wide community of persons" is hopelessly vague. Moreover, these alternatives just go to the number and identity of those benefited. Nowhere does Andrews address the critical question of the magnitude of the benefit to others necessary to deem an expenditure charitable.

This problem infects even Andrews's strongest claim: that the pleasures of giving are free and should not be counted in taxable income. ${ }^{108}$ The pleasure of giving food to a pauper is free in an immediate and tangible sense. The food is there to be consumed. But giving is not always a costless pleasure. If resources are shifted to a person who prizes them less than the donor, or uses them less efficiently, a gift is not free. If $A$ finds joy in giving $B$ a wretched tie, for instance, $A$ 's pleasure is costly because resources are committed to obtaining a tie from which $B$ derives no satisfaction. A gift of a new building named for the donor to a university may be wasteful in a similar way. It has been asserted that the inclination of large donors to give money for highly visible capital improvements results in overspending in that area. ${ }^{109}$ The risk of this type of misallocation is present in all restricted gifts for which the donor dictates a particular use. More broadly, misallocation is possible for all gifts to charity because the use of all gifts are restricted by the charity's goals. A cash gift to the Muscular Dystrophy Association may be wasteful, for example, if excessive resources are committed to research on that disease.

If we try to give content to the concept of freeness, we find ourselves back in the middle of the subsidy theory. As a general matter, the "cost" of an expenditure must be the social loss from diverting resources from alternative uses. That is, an expenditure is "free" if it results in the optimal allocation of resources. Anything else is not free-or is costly-because utility (individual happmess) is sacrificed by being below the optimum. Thus, transfers to charity are "free" only in the circumstance where a deduction may be justified as a device to encourage people to use their resources in a socially optimal way.

Andrews's theory is objectionable, ultimately, because it confuses an already difficult issue. Talking about what is consumption or what is free, as Andrews does, will not help us decide what expenditures on

108 See id. at 356-58.

109 See A. Feld, M. O'Hare, \&-J. Schuster, supra note 44, at 136-41. 
collective goods deserve preference, because those concepts are vague and question begging. Those terms do not provide meaningful criteria for deciding what sorts of expenditures should be deductible as charitable contributions. Arguing that a deduction is appropriate because gifts to charity are not consumption (or that their benefits are free) may make the case for a deduction more palatable, but only by disguising the argument's true flavor.

\section{EQUITY AND THE Altruistic DoNor}

A contributions deduction sometimes is justified on the ground that people who give their resources to charity are thereby made less welloff and so should pay less tax than people who spend their resources on personal consumption. The argument is

that private giving is primarily altruistic, that most people do not enhance their wealth or their power when they give and are not providing for their personal needs, and that they should not therefore be taxed on the amount of money they give away. We think it entirely appropriate, in other words, for the person who earns $\$ 55,000$ and gives $\$ 5,000$ to charitable organizations to be taxed in exactly the same way as the person who earns $\$ 50,000$ and gives away nothing. ${ }^{110}$

The argument has two premises. First, taxable imcome should be adjusted to account for the satisfaction people actually get from their receipts and expenditures. Second, from giving to charity people do not receive pleasure commensurate with other personal expenditures. These two premises will be examined each in turn.

\section{A. Should Satisfaction Matter?}

The argument for adjusting imcome to reflect satisfaction assumes that the burden of taxes ought to be shared among people on the basis of their relative well-being (or ability to pay). ${ }^{111}$ One either agrees with such an "ought" proposition or one does not, and arguing for or against it is beyond the scope of this Article. If one accepts this goal,

110 Commission on Private Philanthropy and Public Needs, supra note 7, at 128; see also Tax Reform for Fairness, supra note 2, at 81 ("Some would argue that a deduction is especially appropriate when charitable contributions of a high percentage of current income substantially reduce the taxpayer's true ability to pay, as measured by income available for private use."); $c f$. Bittker, supra note 7 , at 58-59 (gifts made out of moral obligation should be excluded in determining income).

111 See Andrews, supra note 6, at 313. 
receipts or expenses that do not enhance the welfare of a taxpayer should be deducted or excluded from income. A taxpayer is worse off due to an unsatisfying expense than a person of similar imcome who spent her money in more pleasing ways, and therefore, for reasons of equity, should bear less of a tax burden.

Although it once had some currency, ${ }^{112}$ few scholars today think that we should be concerned with subjective satisfaction in measuring income. (Andrews's defense of a medical expense deduction is a major exception.) Most favor an objective definition of income as property rights (primarily money) accumulated or expended for consumption during the taxable period. ${ }^{113}$ A "rigorous, objective definition" of income is thought essential, as Professor Simons writes, for "[t]he criterion of equity, by itself, leads only to a vague and elusive ideal, not to a sound and workable income tax," 114

But the administrative objection to a satisfaction-based tax is not very telling, at least in the abstract. Workable rules may be formulated on the basis of the likely effect on a person's welfare of a type of receipt, expenditure, or other objective event. A variety of provisions in the Internal Revenue Code in fact take this approach. Casualty losses and medical expenses are deducted because it seems likely that a person who incurs them will be less well-off than her neighbors. ${ }^{115}$ Fringe benefits (e.g., meals or lodging made available to an employee at work) are not taxed because we doubt their value to the recipient. ${ }^{116}$ State and local taxes are deducted because we doubt whether the individual receives benefit equal to her expenditure from local government. ${ }^{117}$ In all these cases the Code balances the fetish for objective criteria for income (money spent and things had) against a concern for the real personal satisfaction derived from them.

The fact that an income tax could account for satisfaction through general rules that look to objective events allays another concern with considering people's feelings in deriving their taxable income. The

112 See I. Fisher, The Nature of Capital and Income 165-79 (1906).

113 See H. Simons, supra note 79, at 49.

114 Id. at 139.

115 See Due, Personal Deductions, in Comprehensive Income Taxation, supra note 68, at 45-46.

116 See H. Simons, supra note 79, at 53 .

117 See Due, supra note 115 , at 50 . Of course there are other reasons for this deduction, such as a desire to minimize friction between federal and state governments over fiscal matters. See id. 
prospect of forcing people to open their hearts to revenue agents has troubled soine scholars. It truly would be objectionable, for example, to require donors to a church to attest to what pleasures they derive from their church before they may deduct their gifts. ${ }^{118}$ But revenue agents need not imquire into individuals' feelings. We should be able to formulate general rules on the basis of our own experience, abstract models of human behavior, or surveys of people in which confidentiality may be protected.

A more pressing concern is that by adjusting income to account for unsatisfying expenditures we reward and encourage waste. For instance, one might object to the exclusion of fringe benefits because it encourages employees to take as benefits resources that could better be put to other uses. But if people truly give to charity for altruistic reasons this should not be a problem. Self-interest motivates an employee to take untaxed fringe benefits even though they are an inefficient use of resources. She may accept a meal that cost her einployer $\$ 5.00$, although she sets only a $\$ 4.00$ value on it, because it is tax free. If she is in a greater than twenty-percent bracket the meal is worth more to her than $\$ 5.00$ of taxed wages. Altruists, however, act differently. They give because they see social value in what a charity does (or they feel duty-bound to give), not because they wish to get a good cheaply with the government picking up part of the tab.

In sum, that people ought to be taxed according to their relative well-being is a plausible allocative goal, and the objections to adjustmg income to account for the effect of receipts and expenditures on well-being are unpersuasive, at least in the case of charitable contributions. If gifts to charity make people worse off a deduction for them may be defended on grounds of equity.

\section{B. The Quality of Charity}

The difficulty with the argument that contributions impoverish donors-and what makes contributions unlike casualty losses, fringe benefits, medical expenses, and state and local taxes-is that the loss seems to be incurred voluntarily. ${ }^{119}$ To many critics of a deduction

118 Cf. Warren, Would a Consumption Tax Be Fairer Than an Income Tax?, 89 Yale L.J. 1081, 1096-97 (1980) (tax based on interpersonal utility comparisons would be impractical and intrusive).

119 Casualty and theft losses come as surprises to the victim. Medical expenses are incurred because of the vicissitudes of health. Employee lodging is excluded from income only if the 
the fact that contributions are voluntary proves they are as satisfying as other expenditures. One asks: "If people don't receive as inuch utility from charity as from their own consumption, why should they give to charity in the first place?" 120 Underlying this question is the assumption that people always behave as traditional economic theory supposes they do-as egoistic, rational utility maximizers. It is taken for granted that "charitable donors are the same as everyone else in an individualist culture: They use their inoney for their own relative benefit."121

But does this description of charity ring true? In describing human behavior it is important not to ignore personal experience, for perhaps the deepest and richest understanding of human motivations can come through self-scrutiny. Ask yourself if you give to charity out of a reasoned judgment that the satisfaction of giving (pleasure found either in the service funded or in the act of giving) matches that of other possible expenditures. That account describes how or why my family gives only in a few cases. Yes, we support public radio and television and the Children's Museum to maintain a service we enjoy. Perhaps we pay membership fees to the Synagogue for similar reasons. We give to our schools out of feelings of obligation for the benefits they have bestowed upon us. My wife's gifts to the United Jewish Appeal seem to follow from a sense of obligation learned from her parents. Our gifts to Amnesty International, Greenpeace, and similar groups also spring from feelings of duty or responsibility. Occasionally gifts are accompanied by feelings of embarrassment that the sum we choose to give is so paltry. Only sometimes does the description of the act of giving as pleasurable in itself, or as perforined in order to receive another source of satisfaction, ring true.

There is also empirical evidence supporting the conclusion that giv-

employee is "required to accept such lodging on the business premises of his employer as a condition of his employment." I.R.C. $\S 119(2)(2)$ (1982). Employee meals are excluded only if the meals are furnished for the convenience of the employer on its business premises. Id. $\S 119(a)(1)$. These provisions restrict the recipient's choice. And, of course, the obligation to pay state and local taxes is imposed by one's neighbors. Cf. Blueprints, supra note 2, at 92 (contrasting "voluntary collective [such] as a social club" with "a larger collective organization, such as a State government ... payments to ... [which are not] good proxies for the value of services received").

$120 \mathrm{H}$. Rosen, Public Finance 350 (1985).

121 Kelman, supra note 2, at 880 . 
ing is not always the result of a rational, utility-maximizing choice. ${ }^{122}$ Psychologists and sociologists who have studied altruistic (or prosocial) behavior have found a variety of causes. An internalized sense of a duty or responsibility to help others, as well as feelings of empathy for other persons, are critical in its developinent. These norms and feehngs seein to be inculcated during early childhood..$^{123}$ Social pressure also plays a significant part. To give because of pressure from friends or persistent solicitors is a common experience. Finally, soine giving is a matter of habit. A person who gives once tends to do so several times more. ${ }^{124}$ These findings are consistent with surveys of charitable donors, who report feehings of approval or obhigation (sixty-seven percent), belonging to a group (twenty-three percent), personal benefit (thirteen percent), and social pressure (five percent) as reasons for giving. ${ }^{125}$

Thus, the egoistic inodels of giving are not very persuasive, and the weakest models are those that try to explain giving as purely egoistic. They attempt to explain giving as a function of the value donors place on the good provided by a charity. ${ }^{126}$ For example, a person who gives a dollar to public broadcasting would, under a purely egoistic model, be assumed to derive a dollar's worth of satisfaction from pubhic broadcasting. If people behave this way we would expect that each dollar the government provides to charity would displace, or crowd out, a dollar of private giving, ${ }^{127}$ because the government's dollar should satisfy the individual's desire for the good. Econoimists also concede that under this model of human behavior we would expect giving to be rare, because a rational agent should prefer to freeride on

122 For a summary of empirical findings relevant to the understanding of altruistic behavior, see Bolnick, Toward a Behavioral Theory of Philanthropic Activity, in Altruism, Morality and Economic Theory 201-16 (E. Phelps ed. 1975).

123 See D. Bar-Tel, Prosocial Behavior 11-31 (1976).

124 See Piliavin, Evans, \& Callero, Learning to "Give to Unnamed Strangers," in Development and Maintenance of Prosocial Behavior 473-80 (E. Staub, D. Bar-Tel, J. Karylowski, \& J. Reykowski eds. 1984).

125 Morgan, Dye, \& Hybels, supra note 44, at 205. The sum of these figures exceeds 100 percent because the two reasons most strongly indicated by each respondent are included.

126 For a criticism of such models, see Sugden, Consistent Conjectures and Voluntary Contributions to Public Goods: Why the Conventional Theory Does Not Work, 27 J. Pub. Econ. 117 (1985); Sugden, On the Economics of Philanthropy, 92 Econ. J. 341 (1982).

127 See Roberts, A Positive Model of Private Charity and Public Transfers, 92 J. Pol. Econ. 136 (1984). 
the efforts of others. ${ }^{128}$ Neither prediction holds true. Public transfers do not crowd out private cliarity dollar for dollar, ${ }^{129}$ and private giving is at a far higlier level tlian one would expect of a society of ultrarational freeriders.

Moreover, as we inove across the spectrum of giving from transfers to family members (which liave a significant reciprocal element), to poor relief, to anonymous gifts of blood, to disaster relief, to actions directed to benefit later generations, the models take on byzantine complexity in order to adduce self-interest in acts of no immediate, or even apparent, benefit to the actor. ${ }^{130}$ Disaster relief is an example. One may construct a model that explains giving in response to disasters as an informal means of insurance, ${ }^{131}$ but the reciprocity is too attenuated for this explanation to be persuasive. The prospective benefit to donors is sliglit and the opportunity for freeriding enormous. Some relief, such as aid to distant impoverislied people wlio suffer a disaster, lacks any discernable reciprocal element. At some point the phenomenon begs explanation by factors extraneous to traditional economic theory.

To deal witl these problems some modify the model to account for the pleasures of altruism. These pleasures are variously described as the joy people derive from the act of giving, from knowing that they liave aided otliers, or from watching others consume. ${ }^{132}$ The equation

128 See A. Atkinson \& J. Stiglitz, supra note 26, at 515.

129 See Abrams \& Schmitz, The 'Crowding-Out' Effect of Governmental Transfers on Private Charitable Contributions, 33 Pub. Choice 29 (1978), reprinted in The Economics of Nonprofit Institutions, supra note 15, at 303. Susan Rose-Ackerman has suggested reasons other than the fact people derive pleasure from giving that may explain why government grants to charities do not crowd out private donations dollar for dollar. Government support may, for example, encourage a charity to alter its services in ways preferred by the public, or enable it better to publicize its needs, or allow it to realize economies of scale that make it more attractive to supporters. See Rose-Ackerman, Do Government Grants to Charity Reduce Private Donations? in Nonprofit Firms in a Three-Sector Economy 95 (M. White ed. 1986), reprinted in The Economics of Nonprofit Institutions, supra note 15 at 313, 325-26 (1986). To the extent that the act of voluntary giving is itself a source of satisfaction, there would be less than dollar-for-dollar crowding out even in a society of rational utility-maximizers.

130 Cf. D. Collard, Altruism and Economy 16 (1978) ("The standard assumption of selfinterest . . . has to be stretched to the very limit to accommodate everyday instances of altruistic conduct. ... [T] [he modifications needed proliferate in an ad hoc fashion. Once this happens to a theory it is perhaps time to look elsewhere.").

131 See Douty, Disasters and Charity: Some Aspects of Cooperative Economic Behavior, 62 Am. Econ. Rev. 580, 586 (1972).

132 See Steinberg, Voluntary Donations and Public Expenditures in a Federalist System, 77 Am. Econ. Rev. 24, 25 (1987). On the difference between the first two pleasures, see Arrow, 
of selfishness is made to balance by accounting for altruism as providing pleasure like ordmary acts of consumption. Thus it is suggested that a person might override her instinct to freeride because she derives some pleasure from acting altruistically, or that she inay continue to support a charity after government has inatched her earhier contributions because the pleasure she derives from giving more than offsets the dininished marginal utility of the additional services funded.

This reasoning is completely circular. That giving is pleasurable follows tautologically from the implicit premise that people would refuse to give if it was not. It is only as strong as the assumption that all human behavior is egoistic, rational, and pleasure seeking. ${ }^{133}$

But accepting that soine gifts are disinterested does not mean that all are, and there remain enormous problems in distinguishing altruistic or self-denying gifts from egoistic gifts. A possible distinction is between reciprocated and unreciprocated gifts. If a person receives soine tangible benefit from a charity to which she contributes, such as entertainment or a place to worship, it does not require too great a leap to conclude that she gives in order to maintain that source of satisfaction. If a sense of duty plays a role it may be of only a contingent duty to pay for a good one enjoys.

This distinction is not completely satisfactory, however. Gifts that seein to be reciprocated inay, in fact, be motivated by soinething other than a desire to support a good. People may give to their church, for example, out of a sense of religious obligation. Unreciprocated gifts may also yield satisfaction. The economists are sometimes right when they say that a person may take pleasure in another person's consumption (consider a parent's pleasure in giving to a child), or that she may take pleasure in knowing that she has helped another.

Amartya Sen has proposed another criterion for distinguishing altruistic froin egoistic giving. In Sen's view, the important difference is between gifts of sympathy and gifts of coinmitment. ${ }^{134}$ Gifts of

Gifts and Exchanges, in Altruism, Morality, and Economic Theory 13, 17-18 (E. Phelps ed. 1975). On the pleasures of watching other people consume, see Becker, A Theory of Social Interactions, 82 J. Pol. Econ. 1063, 1064-66 (1974).

133 Cf. Sen, Rational Fools: A Critique of the Behavioral Foundations of Economic Theory, 6 Phil. \& Pub. Aff. 317, 322-24 (1977) (it is possible to define a person's interests in such a way that any act furthers her "own interests").

134 See id. at 326-29. 
sympathy may be understood as pleasure seeking in the usual sense, Sen observes, because the donor makes them in order to derive pleasure from another person's consumption. Gifts of commitment are motivated by feelings of duty or obligation and may affect the donor quite differently. Commitment "drives a wedge between personal choice and personal welfare"135 and involves "counterpreferential choice, destroymg the crucial assumption that a chosen alternative must be better than (or at least as good as) the others for the person choosing it. ..."136 The purest example of acting out of commitment is giving up one's life for others. ${ }^{137}$

This criterion is not of much help, because it depends upon being able to disentangle closely related motives of sympathy and commitment. We cannot say with confidence, for example, whether a parent aids a child for reasons of pleasure or duty. Probably both are present. If much that a parent does for a child is pleasurable, one wakes up in the middle of the might to go to a child because it is a duty.

But it does not follow that the quality of charity is unknowable in every case. Although it is hard to say for certam whether altruistic behavior is self-abnegating, some charity is so clearly egoistic that a deduction cannot plausibly be justified on equitable grounds. Part IV will identify one such case: giving to public television. Perhaps this sort of negative application-identifying cases where it clearly does not apply -is the best we can do with the equitable argument for now.

\section{APPLICATIONS}

This Part examines churches, public television, and social welfare agencies in an effort to determine whether a deduction or tax credit for gifts to these institutions is justifiable on grounds of efficiency or equity. These three cases pose fundamentally different issues. In the case of churches, the issue of efficiency may be described generally as

135 Id. at 329.

136 Id. at 328.

137 Acting out of commitment may be characterized as satisfaction-seeking behavior, insofar as the act may be done to avoid feelings of guilt. Sen acknowledges this point but does not respond to it, except by claiming that in such a case the immediate cause of the action is commitment. Id. at 327. Perhaps guilt-avoiding behavior may be likened to medical expenditures. A person who feels a strong sense of social obligation is worse off than her happily selfish neighbors because she must commit some of her resources to charity in order to avoid pain her neighbors would never feel. 
whether a club-like collective good which benefits and is supported by a small and socially close group deserves the public support of not taxing its members' contributions. The conclusion is that a deduction is unnecessary because the closeness of the group mitigates against freeriding. A deduction for gifts to churches may, however, be justified on equitable grounds.

Giving to public television is strongly egoistic, so a deduction cannot be justified on equitable grounds. An efficiency justification in this context turns on the relative inerits of supplying a collective good through tax-free giving and providing a good througli the market. The administrative and redistributive arguments for maintaining public television are sinnilar to the arguments for maintaining museums, symplionies, and libraries as free goods.

Social welfare charities are examples of helping charities. The unique freeriding probleins they confront and their redistributional benefits inake thein a strong candidate for subsidy. A credible case may also be made for deducting gifts to social welfare charities on equitable grounds.

\section{A. Churches}

If number of contributions is the measure, churches are by far the most important charities. Over sixty percent of all contributions by individuals is to religious charities. ${ }^{138}$ Churches are self-help cliarities: their supporters are also their primary beneficiaries. ${ }^{139}$ Churches obtain over four-fifths of their income from nienibers, niostly in the form of relatively sinall contributions, and over four-fifths of cliurch income goes to operations and current expenses. In a survey of Protestant churches, alniost ninety percent of inconie came from individual gifts. ${ }^{140}$ Over sixty percent of gifts were in amounts under $\$ 500$ and over eighty percent were less than $\$ 1,000$. About eighty-five per-

138 See C. Clotfelter, supra note 3, at 22; 31 Giving USA, supra note 31, at 11 (1986) (72 percent of individual giving is to religious charities). Almost 48 percent of giving from all sources, including businesses and foundations, is to churches. 30 Giving USA, supra note 31 , at 7 (1985).

139 Cf. Silver, Utilitarian Participation, in Rationality and Society 701, 704 ("If only persons who join in the manufacture of a good participate in its consumption, the situation is one of self-help.").

140 Interfaith Research Comm. of the Comm'n on Private Philanthropy and Public Needs, A Study of Religious Receipts and Expenditures in the United States, 1 Research Papers, supra note 1, at 402 (1977) [hereinafter Religious Receipts]. 
cent of total expenditures were sacramental. ${ }^{141}$ In Catholic parishes, eighty-nine percent of income was from individual contributions (an additional ten percent was from bazaars, bingo, or sales). Nearly ninety percent of these gifts were under $\$ 500$ and ninety-eight percent were under $\$ 1,000$. If Catholic schools are excluded, about ninety percent of income was spent on sacramental purposes. ${ }^{142}$ Individual gifts and tuition account for ninety-four percent of synagogues' income. Eighty percent of gifts were under $\$ 500$ and ninety-five percent were under $\$ 1,000$. Only forty-eight percent of total expenditures were sacramental, but ninety-four percent of nonsacramental expenditures were for education. ${ }^{143}$ Generally, only a small percentage of church resources-at most ten to twenty percent-are devoted to nonsacramental functions, and some of these resources are devoted to services, such as day care or family counseling, that benefit parishioners. ${ }^{144}$

It is fair to assume that most churches cannot be funded through a market mechanism in which people who attend services are required to pay. Some churches have mandatory fees (which are deductible), ${ }^{145}$ but m many religions this would violate strongly held tenets

141 See id. at 403.

142 See Id. at $422-24$.

143 See Id. at 431-34.

144 See C. Clotfelter, supra note 3, at 23-24; 31 Giving USA, supra note 31, at 47 (1986). It was reported in 1982 that while over half the congregations provide some form of social service (e.g. day care, counsehing, food or shelter), only 10 percent spent as much as $\$ 25,000$ on providing such services directly and only 3 percent spent as much as $\$ 25,000$ on providing them indirectly. 30 Giving USA, supra note 31 , at 54-55 (1985).

145 See Rev. Rul. 47, 1970-1 C.B. 49 (pew rentals) (restating T.B.R. 2, 1 C.B. 150 (1919); cf. Rev. Rul. 366, 1978-2 C.B. 241 (bequest for saying mass deductible); Rev. Rul. 580, 1971-2 C.B. 235 (payments for genealogical research on donor's family deductible if research has religious purpose). This is the only instance under current law in which dues paid to a serviceproviding organization in return for a benefit are presumed to be deductible. Dues paid to other organizations, such as museums or alumni associations, are deductible only to the extent they exceed the value of the related benefits. Because the burden is on the taxpayer to prove that there is excess value to be deducted, taxpayers usually lose under this rule when challenged. See Horne v. Commissioner, 16 T.C.M. (CCH) 953, 958 (1957); Rev. Rul. 432, 1968-2 C.B. 104.

Recent cases denying the deduction for fees paid to the Church of Scientology to attend "auditing" and "training" services may imperil the deduction of church dues. United States Courts of Appeals in four circuits have held these fees not deductible, see Lee $v$. Commissioner, 843 F.2d 418 (10th Cir. 1988); Miller v. Commissioner, 829 F.2d 500 (4th Cir. 1987); Graham v. Commissioner, 822 F.2d 844 (9th Cir. 1987), cert. granted, 108 S. Ct. 1994 (1988); Hernandez v. Commissioner, 819 F.2d 1212 (1st Cir. 1987), cert. granted, 108 S Ct. 1467 (1988), while three Courts of Appeals have held them deductible. See Neher v. 
that the church should be open to all. Assuming churches must be funded voluntarily, the issue is whether the benefit to society of increased giving to churches stimulated by a deduction outweighs the cost of a deduction, i.e., whether a deduction is an efficient social policy in the Kaldor-Hicks sense.

The efficiency of a deduction depends largely on the degree of freeriding in churches. Freeriding is a problem if it causes people to fall short of supporting a good at a level where the sum of the marginal benefits from the last unit funded equals the marginal cost of that unit; that is, if freeriding behavior results in a level of expenditure short of that achieved in a Lindahl solution. If freeriding is not a problem, im the way just defined, then a deduction generally cannot be efficient, because with a deduction the marginal cost of an additional increment of a good will exceed the sum of people's marginal benefits. For example, assume a two-person good costing $\$ 4.00$ a unit. Each person values one unit at $\$ 10.00$, two at $\$ 9.00$, three at $\$ 8.00$, and so forth, valuing eleven or more umits at $\$ 0$. If they fund the good at the optimal nimth unt without a deduction, allowing a deduction will encourage them to buy the tenth unit though its cost (\$4.00) is greater than its benefit to them ( $\$ 2.00)$. Further, the degree to which a good is underfunded because of freeriding affects the magnitude of the benefit of a deduction. People will reap greater benefit per dollar spent on a charity the further they fall short of funding the optimal level of a good (assuming they have downward sloping indifference curves). In the example, the return from a deduction is greater if it increases funding from three units to four (a $\$ 4.00$ unit provides a $\$ 14.00$ bene-

Commissioner, 852 F.2d 848 (6th Cir. 1988); Foley v. Commissioner, 844 F.2d 94 (2d Cir. 1988); Staples v. Commissioner, 821 F.2d 1324 (8th Cir. 1987). Courts that have denied a deduction have reasoned that payments to a church for which consideration is received are not charitable contributions, and have rejected arguments that religious services cannot be cognizable consideration. This reasoning calls into the question the earlier rulings allowing a deduction. Indeed, the Ninth Circuit commented that "we are not convinced that every one of those rulings would comport with the analysis of [S]ection 170 that we have set forth here." Graham, 822 F.2d at 850 .

One suspects that the Scientologists suffer because of skepticism about their religious practices. Almost all religious giving is reciprocal in the sense that people who give benefit directly from church services. It was because pew fees are indistinguishable from basket collections that the I.R.S. first ruled that pew fees are deductible. T.B.R. 2, 1 C.B. 150 (1919). That the Scientologists formalize the exchange implicit in almost all religious giving is hardly grounds for denying a deduction, unless one thinks form is more important than substance. 
fit) than if it increases funding from eight units to nine (a $\$ 4.00$ unit provides a $\$ 4.00$ benefit).

Thus, the first issue in assessing the efficiency of a contributions deduction for churches is the extent to which they suffer from freeriding. Do people fail to give to churches though it is in their collective interest to do so? And how far do they fall short of the optimum?

In determining the degree of religious freeriding, people who are not members of churches probably can be disregarded. Members should have a sufficient incentive to fund churches at a level nonmembers find satisfactory. An oft-claimed social benefit from churches is the moral and religious education of members, particularly children. ${ }^{146}$ Religious education is the sort of thing we would expect parents and church members to provide on their own. Parents have a strong interest in the moral education of their children. They must live with their children and many suffer when their children sin. Churches must win over children if they are to survive as institutions. If religious education is worth the price to parent or the congregation, then, using our earlier terminology, nonmembers are privileged and need not pay for churches to provide an optimal level of services. ${ }^{147}$

To determine the incidence of freeriding among church ineinbers we theoretically could assess the cost of varying levels of church services and survey inembers to determine how inuch they would be willing to spend for each level. Members ideally would also tell us how much tliey would contribute for a given level of services with and without a deduction. Assuming inembers honestly revealed their preferences and likely contributions, such a survey would reveal whether without a deduction members would collectively spend less on their church than is cost-efficient. ${ }^{148}$

146 Cases extolling the benefits of religion to society generally are collected in E. Fisch, D. Freed, \& E. Schachter, Charities and Charitable Foundations § 273, nn.10-13 (1974).

147 See supra notes 54-56 and accompanying text.

148 To ensure preferences are accurately revealed it would be important that members be asked how much they are willing to pay for services. A reccnt study found that asking people what a good is worth to them results in their overstating preferences. On the other hand, the study found that if people were asked how much they would pay for a good it did not seem to matter how they were told the costs would be allocated. Five different methods to share costs were proposed. Different groups of subjects were told that each would pay the amount he said he was willing to pay; that costs would be shared equally; that costs would be apportioned in accordance with willingness to pay; that how costs would be apportioned would be determined later; and that there was no expectation of payment-but the groups did not differ significantly in their expressed preferences. See Bohm, Estimating the Demand for Public Goods: An 
What data there is suggests that churches probably do not suffer greatly from freeriding, or at least do not suffer as much from freeriding as do most other charities. The club-hke orgamzation of churches mitigates the problem of freeriding. Churches are able to adjust expenditures and fund-raismg efforts to suit members' preferences. They are run by people (members or clergy) with close ties to members who should be aware of what members want. ${ }^{149}$ Church members are relatively few in number, ${ }^{150}$ they are socially related, ${ }^{151}$ and giving is often visible. ${ }^{152}$ As a result, there can be effective external pressure from fellow members to discourage freeriding. And there is internal pressure to give. The small size of a church makes it clear to members that its maintenance depends on their support. Religious teachings also combat freeriding because they emphasize obhigation to

Experiment, 3 Euro. Econ. Rev. 111, 112 (1972). This result is significant, and heartening, because it suggests that people tend to reveal preferences honestly without considering how they might take advantage of different schemes for allocating costs. Cf. Bohm, An Approach to the Problem of Estimating Demand for Public Goods, 73 Swedish J. Econ. 55, 56 (1971) (faced with uncertainty about how the costs of a good will be allocated people may simply tell the truth about how much they would pay for it).

149 Giving is very responsive to levels of programs or services. See Cieslak, Parish Responsiveness and Parishioner Commitment, 26 Rev. Religious Res. 132, 140 (1984).

150 There is evidence that size of a congregation is strongly correlated to amounts given. See Hilker, Voluntary Contributions and Monitoring Efforts: Revealed Preferences for the Services of Religious Organizations, 19 J. Sci. Study Rehigion 138 (1980). In his pioneering work, Mancur Oison hypothesized that small groups would find it easier than large groups to overcome problems with acting collectively. See M. Olson, The Logic of Collective Action 48 (1971). This hypothesis has been extensively debated. The upshot of the debate is that the hypothesis will not hold true for all goods. If a good is truly jointly supplied (i.e., there is no marginal cost for each additional user) large groups may be more likely to succeed because as the size of the group increases a smaller percentage of the group may fund a good. For example, if the lights go out in a building, the greater the number of people affected the more likely it is someone will call building services. See Bhiss \& Nalebuff, Dragon-Slaying and Ballroom Dancing: The Private Supply of a Public Good, 25 J. Pub. Econ. 1 (1984); Oliver \& Marwell, The Paradox of Group Size in Collective Action: A Theory of Critieal Mass II, 53 Am. Soc. Rev. 1 (1988); cf. R. Hardin, supra note 54, at $42-49$ (discussing this and other variables affecting to what extent difficulty of cooperative action is a function of group size).

151 That socially related groups should find it easier to overcome collective action problems is often noted. See R. Hardin, supra note 54, at 31-35; Obler, Private Giving in the Welfare State, 11 Brit. J. Pol. Sci. 17, 26 (1981).

152 Some churches publish lists of donors, see K. Lutterman, Giving to Churches: A Sociological Study of the Contributions to Eight Cathohic and Lutheran Churches 6-16 (Ph. D. thesis, University of Wisconsin 1962), while in others contributions are kept private. See id. at 6-23. 
a deity or to the community. ${ }^{153}$

Churches are successful in obtaining contributions from members. Some surveys report that fewer than one in ten members do not give, ${ }^{154}$ and most gifts are of respectable size. In 1984, the average gift (in the course of a year) to Protestant churches was $\$ 267.60 ;^{155}$ in 1967, forty-nine percent of members of Protestant churches reported giving $\$ 4.00$ or more at weekly collection. ${ }^{156}$ The high rate of support from members is particularly striking given the fact that many members do not attend church regularly. Probably an even higher percentage of those who attend church give because most donations are made at services. ${ }^{157}$ Of course, this data is not conclusive. It is possible that members are undergiving.

That religious giving may be highly price sensitive (with the absolute value of reported elasticities ranging from 1.60 to $2.15^{158}$ ) is beside the point. High elasticity suggests only that a deduction is a source of significant revenue to churches. The efficiency of a deduction depends on the relative inagnitudes of the cost of what is purchased and the benefit of what is purchased, and what is foregone

153 There is some evidence that church attendance is positively correlated with altruistic behavior. See Langford \& Langford, Review of the Polls: Church Attendance and SelfPerceived Altruism, 13 J. Sci. Study Religion 221 (1974); Nelson \& Dynes, The Impact of Devotionalism and Attendance on Ordinary and Emergency Helping Behavior, $15 \mathrm{~J}$. Sci. Study Religion 47 (1976). But see C. Glock, B. Ringer, \& E. Babble, To Comfort and to Challenge 182-183 (1967) (finding "no discernible relationship" between involvement and charitable acts).

154 See K. Lutterman, supra note 152, at 7-2 (in all eight churches surveyed less than 10 percent gave nothing; in four less than 20 percent gave less than $\$ 20$ weekly); R. Stark \& C. Glock, American Piety: The Nature of Religious Commitment 95-98 (1968) (6 percent of Protestant and 11 percent of Catholic church members reported giving less than $\$ 1.00$ per week); Hoge \& Carrol, Determinants of Commitment and Participation in Suburban Protestant Churches, 17 J. Sci. Study Religion 107, 111 (1978) (18 percent of members gave $\$ 100$ or less to their church in a year).

155 30 Giving USA, supra note 31 , at 52 (1985).

156 R. Stark \& C. Glock, supra note 154 , at $95-98$ (40 percent reported giving $\$ 1.00$ to \$3.99).

15730 Giving USA, supra note 31 , at 47 (1985). The correlation of giving to attendance is well-documented. See 31 Giving USA, supra note 31, at 52-53 (1986) (reporting that regular church-goers give 3.1 percent of income to religious charities, people who attend 1-2 times per month give 1.3 percent, people who attend a few times a year give 0.7 percent, people who never attend give 0.2 percent); Cornwall, Albrecht, Cunningham \& Pitcher, The Dimensions of Religiosity: A Conceptual Model With An Empirical Test, 27 Rev. Religious Res. 226, 240 (1986) (in the Church of the Latter Day Saints, percentage of income paid to church is highly correlated with attendance at meeting).

158 C. Clotfelter, supra note 3 , at 64-66. There are studies with contrary findings. Id. 
because of the additional deducted contributions. High elasticity is entirely consistent with waste. For example, consider a one unit church which costs $\$ 60$ per member, but which members value at only $\$ 40$. Members would not support the church if a deduction did not decrease the cost of a $\$ 60$ gift to no more than $\$ 40$. A deduction is inefficient if the churchmembers are in a thirty-three percent bracket, because each member will spend $\$ 60$ on a good providmg $\$ 40$ worth of satisfaction. Yet the level of giving in this case is extraordinarily price sensitive: a revenue loss of $\$ 20$ per member increases giving by $\$ 60$.

Even if there is some degree of freeriding within a church and the benefit to members of the additional services funded because of a deduction exceeds the costs of those services, a deduction for contributions may be inefficient, because the cost of a deduction is borne by all of society. A deduction thus redistributes wealth from nonmembers of a church to members. ${ }^{159}$ If nonmembers would have derived greater utihty from this redistributed amount, a deduction is inefficient. For example, if each member in a 100 -member church values an organ at $\$ 100$ and an organ costs $\$ 10,000$, it is efficient from an internal perspective for members to purchase the organ because its benefits to them equal its costs. But funding the organ through a contributions deduction may be inefficient because part of its cost is borne by nonmembers $(\$ 2,800$ in revenue will be lost if all members are in a twenty-eight percent bracket) who may place greater value than do members on that inoney. To the extent the cost is borne by the poor, for example, either in the form of increased taxes or reduced government funding of services, the money probably would be spent more productively on food or clothing for the poor than by meinbers on the organ.

A deduction for religious gifts inay have precisely this sort of perverse distributional effect. Giving to churches is likely to have two distributional consequences. Within a church there is probably some downward redistribution. Voluntary giving permits informal price

159 Because two-thirds of contributions is to religious charities the cost of a deduction for religious gifts may be estimated at $\$ 8$ billion of the $\$ 12$ billion cost of a deduction (in 1989). See Staff of Joint Comm. on Taxation, supra note 30, at 14-15. Spread across 90 million households, this is $\$ 88$ per household. The actual cost is surely less because religious gifts are made disproportionately by low-bracket taxpayers who save less from a deduction, and whose gifts are likely to be in relatively small amounts. 
discrimination in which the rich pay more and the poor less to support a church, ${ }^{160}$ a pattern that sometimes is formalized when churches assess dues on the basis of ability to pay. ${ }^{161}$ Thus, the top ten percent of rehigious donors account for shightly over twenty-five percent of amounts given to churches and the top twenty percent account for around fifty percent. ${ }^{162}$ (This effect is not as pronounced in churches as it is in other charities. In schools, for example, the top one-tenth of one percent of gifts has accounted for over twenty-five percent of amounts given. ${ }^{163}$ ) But a deduction for religious gifts has a second effect that may redistribute resources upward. Churches tend to be segregated by wealth and race (or ethnicity), ${ }^{164}$ so that when well-to-do people give to churches, their donations tend to benefit people like themselves and not the poor. The cost of a deduction, on the other hand, may bear most heavily on the poor because many of the federal programs imperiled by a loss of revenues benefit them. Thus, to put it sharply, a deduction for religious contributions may support churches of the well-to-do on the backs of the poor.

A deduction has other costs. There is the offense to atheists and agnostics in being forced to pay for churches. There is the effort wasted in attempt to take advantage of the vague definition of religion and the government's efforts to thwart those attempts. ${ }^{165}$ There is

160 Cf. Hansmann, The Role of Nonprofit Enterprise, 89 Yale L.J. 835, 856 (1980), reprinted in The Economics of Nonprofit Institutions, supra note 15, at 57, 69 (discussing contributions to performing-arts charities as a form of voluntary price discrimination).

161 See Nuesse, The Relation of Financial Assessments to Status in a Rural Parish, 9 Am. Catholic Soc. Rev. 26, 27 (1948); see also K. Lutterman, supra note 152, at 6-14 to 6-16 (reporting that solicitations are sensitive to ability to pay).

162 See Religious Receipts, supra note 140, at 376. Lutterman also found that wealthier parishioners tended to give more but not much more. Amounts contributed increased with income but percentage of income contributed decreased. See $K$. Lutterman, supra note 152 , at 8-16 to $8-22$.

163 Levi, Financing Education and the Effect of the Tax Laws, 39 Law \& Contemp. Problems 75, 92-93 (1975).

164 See Bahr, Shifts in the Denominational Demography of Middletown 1924-1977, $21 \mathrm{~J}$. Sci. Study Religion, 99, 111-12 (1982) (but noting some convergence recently); Goldschmidt, Class Denominationalism in Rural California Churches, 49 Am. J. Soc. 348 (1944); Laumann, The Social Structure of Religious and Ethnoreligious Groups in a Metropolitan Community, 34 Am. Soc. Rev. 182 (1969). Interdemoninational differences in wealth and education of members are well documented at a national level. See McKinney \& Roof, A Social Profile of American Religious Groups, in Yearbook of American and Canadian Churches 267 (1982).

${ }_{165}$ This area of litigation is a monument to human imagination. In one case, a purported sun worshipper claimed a deduction for a trip to Puerto Rico. See Kessler v. Commissioner, 87 T.C. 1285 (1986); cf. Church of the Chosen People v. United States, 548 F. Supp. 1247 (D. 
also the cost of government intrusion into churches to guard against abuse (usually private inurement). ${ }^{166}$ The uncertain benefits of a deduction for contributions to churches and its distributional and administrative costs make it hard to justify a deduction on grounds of efficiency.

The equitable argument for deducting religious contributions is stronger. The issue is whether gifts are self-abnegating. Do people give to churches for services received or for the pleasure of giving, or do they give out of a sense of obligation or commitment? Although there is undoubtedly some satisfaction derived from religious giving there is also a significant element of obligation. Under the biblical standard of the tithe members of the church are required to return one-tenth of their income to the Lord. This admomition remains the rule in conservative Protestant denominations which place strong emphasis on biblical doctrine. It is striking that in those denommations average individual contributions are four times greater than in other Protestant denommations. ${ }^{167}$ And even in churches where the biblical injunction has lost its force giving may be from a sense of taught or revealed obhigation. One survey found that important reasons for giving to religious organizations include obligation (sixtynine percent of responses) and the anibiguous feehing that "we belong there" (forty-four percent); only eight percent said they gave because they "get some benefit."168 Another study of church solicitations found appeals to such motives as duty, gratitude, love of God, fear,

Minn. 1982) (homosexual group claiming tax-exempt status as a religious organization); First Libertarian Church v. Commissioner, 74 T.C. 396 (1980) (libertarians making same claim). People have also tried to evade the tax by incorporating themselves or their families as churches to which their income is committed and which pay their personal expenses. See National Ass'n of Am. Churches v. Commissioner, 82 T.C. 18 (1984); Ecclesiastical Order of the ISM of AM, Inc. v. Commissioner, 80 T.C. 833 (1983); Bubbling Well Church of Universal Love v. Commissioner, 74 T.C. 531 (1980); Basic Bible Clurch v. Commissioner, 74 T.C. 846 (1980).

166 In cliallenging the revocation of its exempt status The Church of Scientology has voiced great concern over government delving into church administration. Church of Scientology of California v. Commissioner, 823 F.2d 1310 (9th Cir. 1987), cert. pending, 56 U.S.L.W. 3673 (March 29, 1988).

167 See A Study of Religious Receipts, supra note 140, at 384-85; cf. McGaw, Commitment and Religious Community: A Comparison of a Charismatic and a Mainline Congregation, 18 J. Sci. Study Religion 146, 153-54 (1979) (Charismatic church has twice as many contributions over $\$ 1,000$ as does a Mamline cliurch).

168 Morgan, Dye, \& Hybels, supra note 44, at 204-05. 
reward, and self-fulfillment. ${ }^{169}$ These results provide at least some evidence that giving is felt as an obligation. There is, however, evidence that gifts to churches are very price sensitive (with elasticities with an absolute value of 1.60 or more). ${ }^{170}$ This sensitivity suggests that religious giving, at least beyond a certain amount, is not perceived by some as a inatter of deep obligation. Why people give to churches and what benefits they receive from thein are issues deserving more attention, if one is willing to accept an equitable justification in principle.

\section{B. Public Television}

There is little possibility that much giving to public television is self-abnegating. Public television stations appeal to self-interest in their fund-raising drives. Viewers are asked to support programs they enjoy and stations schedule the most popular prograins during pledge drives. The average gift is small (averaging $\$ 25$ per household in 1978). ${ }^{171}$ This sinall amount is easily explained as the value donors place on the programming. ${ }^{172}$ If contributions to public television are like those to other cultural charities, the amount given is highly correlated with the degree of use. ${ }^{173}$ If altruism plays a part in giving to public television, it is only in suppressing the tendency to freeride.

Thus, a deduction for contributions to public television must be justified on economic grounds. ${ }^{174}$ If the services now provided by public television could only be delivered through the current voluntary sys-

$169 \mathrm{~K}$. Lutterman, supra note 15 , at 6-24 to $6-33$.

170 C. Clotfelter, supra note 3 , at $64-66$. There are studies to the contrary. Id.

171 See Carnegie Comm'n, A Public Trust: The Report of the Carnegie Commission on the Future of Public Broadcasting 112-13 (1979). Other cultural charities report small median contributions. Twenty-five dollars was the median contribution for households of $\$ 30,000$ to $\$ 50,000$ income in 1973. Id. at 35 . In 1984 , the median amount for all gifts was $\$ 48.50 .30$ Giving USA, supra note 31 , at 87 (1985).

172 To be more precise, donors may pay less than the value of the programming received if they believe that their doing so will not reduce the amount or quality of programming. In any event, no donor would be expected to pay more than the value of the programming to her.

173 See 30 Giving USA, supra note 31, at 87 (1985) (reporting Louis Harris pol1); see also A. Feld, M. O'Hare, \& J. Schuster, supra note 44 , at $90-92$ (people with high incomes tend to attend more often and give more).

174 The cost of a deduction in this case is peanuts. Around $\$ 225$ million is given by individuals to public broadcasting each year. At the highest marginal rate (33 percent), the revenue loss would from deductions of this amount would be $\$ 75$ million, which works out to slightly less than $\$ 1.00$ per household if spread evenly. 
tem, a strong argument could be made for a contributions deduction. Unlike churches, public television may suffer from a serious freerider problem. There are a multitude of viewers, so people are likely to think their support unnecessary. Furthermore, people watcli and give anonymously, so that little external pressure can be brouglit on viewers to give. Indeed, only one in ten viewers gives to public television. ${ }^{175}$ In a voluntary system, a credit or deduction for gifts may be the best way to offset freeriding.

Nonetlieless, a market system may be a practical alternative to funding througlı voluntary giving. ${ }^{176}$ Modern teclinology makes this feasible. In areas with establislied cable systems, the programming now on public television could join other "arts" programming on pay cable. In other areas, tlie programming could be scrambled and decoders sold.

Generally, where it is feasible, a market strategy for providing a good is preferable to a strategy of tax-free voluntary giving. A market strategy effectively excludes freeriders, and therefore can provide (where desired) a greater level of funding for a good than a deduction, which recaptures only some of the benefits of freeriding. A market strategy imposes no costs on people disinterested in a good. Although in some circumstances voluntary giving miglit itself be of utility, because of the pleasures of giving, whatever pleasure people derive from givmg to public television probably is more tlian offset by the obnoxiousness of fund drives.

The arguments for continuing to provide public television as a free good outside the market are of doubtful merit. One concern is that the structure of the cable industry makes it an imperfect mechanism for responding to viewer preferences. To the extent people do not want to purchase basic cable services they will be dissuaded from buy-

175 See Carnegie Comm'n, supra note 171 , at 112-13. This does not necessarily mean freeriding is a problem for public television. It may be that asymmetries in preferences and the "lumpiness" of public television mean that relatively few viewers-even one in ten or less-can fund it at an optimal level without the help of a deduction. Recall Howard Hughes' westerns. See supra text accompanying note 56.

176 The analysis here may not apply to public radio because it may not be feasible to charge listeners. A radio station would have to look to advertisers for support. This dependence on advertising deprives the audience of direct influence over programming and diminishes the quality of the good by introducing commercials. Both effects are likely to make the service less satisfactory to viewers than that furnished by a listener-supported station. See Hansmann, supra note 160 , at $849-51$. 
ing public television programming. ${ }^{177}$ If public television is packaged with other programming (either as a basic or premium channel) it will be unclear what consumers are buying, and cable companies could only estimate how much public television is worth to viewers. It may be that we need to keep public television on the air (literally) to keep cable companies from enjoying a monopoly over broadcasting. But appropriate regulation of cable programming should ensure the desired level of whatever one considers "quality television," assuming such regulation is constitutional. ${ }^{178}$

Another concern is the effect of a market strategy on the behavior of public television managers. ${ }^{179}$ Perhaps the need to attract buyers will make inanagers less inchined to produce and broadcast innovative or controversial programming. But this tendency is present already. To win support from "subscribers" station managers produce what they describe as "market-oriented" programining. ${ }^{180}$ It may be that a voluntary system makes the problem worse. Because only one in ten viewers gives, public stations must please a broader audience to win the support necessary to fund a program. The higher the percentage of viewers that pay, the smaller the audience needed to fund the programming. Indeed, there is much innovation and experimentation in music, film, literature, and other media in which artists find their audience (and patrons) through the inarketplaces of clubs, theatres, and bookstores.

A related concern is that programming under a market strategy will more disproportionately reflect the tastes of the well-to-do, who can afford to buy the service. Again, though, this problem is probably at least as great in a voluntary system. "Subscriber-driven programming is designed specifically to appeal to the 10 percent of upscale

177 Public television could remain nonprofit even if its services were sold. Other nonprofit entities, like the Virginia Law Review, sell their services to consumers.

178 But see Century Communications Corp. v. FCC, 835 F.2d 292 (D.C. Cir. 1987), cert. pending no. 87-1510 (FCC rules requiring cable companies to carry local stations violate first amendment).

179 Private giving and profits from auctions accounted for only 23 percent of public broadcasting revenue in 1983 (another 13.7 percent was given by businesses, much of it inkind). 30 Giving USA, supra note 31 , at 88 (1985). The importance of private giving has increased in recent years as federal contributions have decreased. Id. at 91.

180 See Public Broadcasting-The 20th Anniversary: Hearing Before Subcomm. on Communications of the Senate Comm. on Commerce, Science, and Transportation, 100th Cong., 1st Sess. 27 (1987) (statement of Loni Ding, President of Vox Communications.) 
public television viewers who send their contributions." 181 The wellto-do are more hikely to give for a variety of reasons: the upside-down effect makes it cheaper for the wealthy to give, ${ }^{182}$ they can afford to give more and are less hikely to think their contributions unimportant, they inay be accustomed to giving, and managers will work harder for their support because one large gift will seem cheaper to obtain than a hundred sinall ones.

A more telling concern is distributional. A voluntary system inakes public television free to many. This benefits poor viewers who could not afford to pay for the service on cable and many other viewers who could afford to pay for the service but would not. Although there is some truth in this objection to a inarket strategy, the distributional benefits of cultural charities such as museuins, symphonies, and libraries are often overstated. Giving to these charities moves resources "down the income scale: the money [is] raised rather more from the rich and given rather more to the less rich." 183 But the beneficiaries tend to be the iniddle class and not the poor. It has been said of money raised to support cultural charities generally that "the benefits will not accrue to the poor; the lion's share will be received by people with incomes between $\$ 10,000$ and $\$ 25,000$, and nearly a fifth still will be spent to benefit those with incomes over $\$ 30,000 . " 184$ (The redistributive effect inay be even less pronounced than these figures suggest, for many lower incoine beneficiaries are the children of the upper class. ${ }^{185}$ ) This pattern is repeated in the case of public television. Viewers of public television tend to be well-to-do, although there are more poor users than is the case with other cultural charities. ${ }^{186}$

181 Id.

182 See supra note 37 and accompanying text.

183 A. Feld, M. O'Hare, \& J. Schuster, supra note 44, at 90-92.

184 Id. at 93.

185 See id. at 74-75. The authors try to control for this distortion by imputing a higher income to respondents who identified themselves as college students.

186 Of households with incomes over $\$ 20,000,52.3$ percent watched public television at least once a week. In addition, 42.6 percent of households with incomes from $\$ 15,000$ to $\$ 20,000$, 36.7 percent of households with incomes from $\$ 10,000$ to $\$ 15,000$, and 29.8 percent of households with incomes below $\$ 10,000$ watched at least once a week. Carnegie Comm'n, supra note 171, at 339 . Differences in use by educational attainment are slightly more pronounced. Id. These results are borne out by other studies. R. Frank \& M. Greenberg, The Public's Use of Television 175 (1980) (60 percent of households with income below $\$ 8,000$ 
There is no reason, however, why the poor could not be as well served within the framework of a general market system. Broadcasters could be required to waive charges for families that can demonstrate need on the basis of their tax returns, or the service could be provided freely to neighborhoods that are predominately low imcome. Either approach maimtams service for the poor while increasing its funding by extracting payment from well-to-do freeriders.

There is, finally, the argument that public television should continue to be freely provided because its educational programming provides especially important public benefits. A problem with this argument is that much programining on public television is not educational. Further, it is not clear that people who do watch educational programs would not subscribe to a service providing the programs. Certainly there is a thriving market in educational books (many based on public television programs). If some viewers tuned out because they could not afford to subscribe, it is possible to provide them the good without charge. If the fear is that people not predisposed to use the service will not try it, even though they can afford to subscribe, opportumities to sample the service may be provided.

\section{Social Welfare Agencies}

A deduction for gifts to social welfare charities, such as the Salvation Army, poses the same issue as does a deduction for gifts to churches or public television. Some people do not value what these charities do. A deduction taxes the Scrooges of the world, and so makes them worse off, to benefit donors to social welfare charities and the people such charities help. The issue on an efficiency analysis is whether the benefits of a deduction outweigh its costs. ${ }^{187}$

Social welfare charities are different from churches and public television in a way that makes the economic argument for a deduction far stronger. Churches and public television are self-help charities; they are supported by their primary beneficiaries. Social welfare charities are helping charities; their supporters and beneficiaries are separate

never watch public television, while only 31 percent of households with income above $\$ 17,500$ never watch). Hicks.

187 Again, the appropriate criterion for whether a deduction is efficient is that of Kaldor- 
groups. ${ }^{188}$

This separation of supporters and beneficiaries makes it impossible to provide a good through the market. ${ }^{189}$ Needy beneficiaries cannot be charged for the assistance they receive, and nondonors cannot be excluded from most of the benefits donors get from giving (e.g., relieving the pain of seeing people in distress, insurance, and social peace).

Many social welfare charities probably also suffer significantly from freeriding. People are least likely to support a collective good when they think that their contribution is infinitesimal in relation to what needs to be done and therefore can make no real difference. ${ }^{190}$ This perception invites strategic freeriding ("The rest of the world can do it without me.") or resignation ("What difference can I make?"). The task of helping the poor is so daunting that people are likely to respond to solicitations from poor relief charities in precisely this way, especially in large urban areas. ${ }^{191}$ The likelihood of freeriding strongly suggests that, even from the perspective of the well-to-do, social welfare charities are underfunded. A deduction counteracts the tendency to settle at a suboptimal level of funding because of freeriding.

A deduction for gifts to social welfare charities also has a desirable redistributive effect. It shifts resources from the wealthy to the needy. ${ }^{192}$ The benefit of a deduction to the needy, if it increases giving, is likely to be enormous. People witlout food, shelter, or medical care prize those tlimgs highly. Any movement of resources far down the income scale is likely to enhance aggregate welfare because a poor

188 The separation of supporters and primary beneficiaries makes the case for a deduction weaker in one respect. Supporters are unlikely to have accurate information about the success of their charities' efforts. For example, people who give to the Salvation Army are not likely to know how effective the agency is. Cf. Rabin, Charitable Trusts and Charitable Deductions, 41 N.Y.U. L. Rev. 912, 923 (1966) (donors to medical charities often err because they lack information about relative needs of other charitable causes).

189 Cf. Silver, supra note 139, at 715 (noting impossibility of exclusion).

190 See M. Olson, supra note 150 , at 48 .

191 Charities such as the Red Cross may not face the same problem when pleas are made for help in a specific disaster. The human scale of the task and prior successes of such efforts may encourage donors to think their contributions do make a difference.

192 To measure the value of a deduction to the needy we could ask them how much they would pay to avoid losing additional benefits funded because of a deduction (or, how much they would lose because of the repeal of a deduction). Here Markovits' reformulation of Kaldor-Hicks, see supra note 57 , may strongly affect the result because it will reflect the greater relative importance of resources to the poor. 
man will think more of what a dollar buys than does a rich man. ${ }^{193}$

If we combine these two effects-the benefit to relatively wealthy donors from alleviating freeriding and the direct benefit to the poora credit or deduction for contributions to social welfare charities can produce extraordmary returns. Or, as has been said elsewhere, if we assuine that donors to helping charities derive satisfaction equivalent to other expenditures and that transfers are perfectly effective (every dollar given goes to a needy person), then "[i]t is clear ... we want to have the largest tax credit possible. The subsidization of charitable contributions is Pareto-improving, since it raises both the income of [the aged or handicapped] and the utihty derived from giving by the donors." 194 This is not quite true, for people who are disinterested in social welfare will lose because of the revenue loss from a deduction. But their loss should be more than made up by the benefit to people helped by social welfare charities because the revenue cost of a deduction is only a small portion of the dollar value of the resources transferred.

A strong case can also be made that gifts to social welfare charities are self-abnegating and should be deductible on equitable grounds. The fact that supporters of these charities reap only attenuated secondary benefits, plus the enormous opportumities for freeriding, makes giving to social welfare charities hard to explain with egoistic models. Although one may conceive of the act of giving as itself a source of pleasure, there is evidence to the contrary in surveys of blood donors, who, hike most donors to social welfare agencies, make small gifts to aid anonymous people. Blood donors say they are "pushed" to give by feehings of social responsibility, desires to live up to moral standards, and social pressure. ${ }^{195}$ There is little mention of pleasure. The great good done by these charities makes credible claims that gifts to them are motivated by feelings of social obligation.

193 Increased money spent on social welfare charities will not always be of utility to the poor, of course. Money may be spent on administration (or fund raising) without benefiting the needy. In cases of isolated, highly publicized deprivation (children needing operations or small towns wiped out by tornados), too much may be devoted to a cause relative to other needs. And, there may be a risk of charity trapping the poor in positions of dependency.

194 Atkinson, supra note 11, at 20.

195 R. Titmuss, supra note 46, at $88-89,224-36$; see Piliavin, Evans, \& Callero, supra note 124 , at $473-80$ (discussing blood donors' motivations). 


\section{Conclusion}

From the perspective of efficiency or equity, gifts to many charities that now are deductible should not be. The definition of charity under Section 170 is surely flawed at its margins: it is ludicrous that sports museums, ${ }^{196}$ jazz festivals, ${ }^{197}$ and smging groups ${ }^{198}$ are treated as charities. Alternative methods of ensuring that beneficiaries of these services support them at desired levels are readily available, and it is implausible that gifts to these charities are altruistic im motive. There are strong arguments on both efficiency and equity grounds that a deduction is appropriate in the case of social welfare charities. In regard to religious contributions, the two rationales may lead to different policies. Although the efficiency argument is rather weak, there is at least a colorable equity argument given the information now available. The fact that the equity rationale may support a deduction for a substantial class of charitable deductions for which efficiency justifications do not should stimulate further exammation of its psychological and normative premises.

196 Rev. Rul. 372, 1968-2 C.B. 205.

197 Rev. Rul. 271, 1965-2 C.B. 161.

198 Rev. Rul. 46, 1966-1 C.B. 133. 